\title{
23. SEDIMENTARY HISTORY OF THE RED SEA ${ }^{1}$
}

\author{
Peter Stoffers, Laboratorium für Sedimentforschung, Universität Heidelberg, \\ Heidelberg, Germany \\ and
}

David A. Ross, Woods Hole Oceanographic Institution, Woods Hole, Massachusetts

\section{INTRODUCTION}

Numerous studies have been made of Recent Red Sea sediments concerning their paleontology, mineralogy, or geochemistry. In addition, over 50 reports have been published on the sedimentary environment of the hot brine area $\left(21^{\circ} \mathrm{N}\right)$ in the central axial valley (see Degens and Ross, 1969, and contained references; Bäcker and Schoell, 1972). These studies generally indicate considerable climatic fluctuations within the Holocene and Late Pleistocene that are reflected by changes in fauna and sediment characteristics. In general, aragonite-cemented lithic layers formed during periods of glacially or tectonically lowered stands of sea level when salinity increased in the Red Sea (Milliman et al., 1969). Lowered sea level would restrict inflow of Indian Ocean water from the Straits of Bab el Mandeb. This, combined with the high evaporation rate prevailing over the Red Sea, would result in increased salinity during these periods. Benthonic foraminifera also reflect higher salinities in that there is an increased presence of forms tolerant of high salinity during the times of lowered sea level. Geochemical investigations (Deuser and

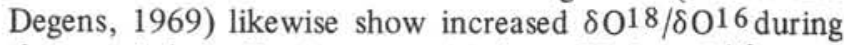
these periods, indicating evaporitic loss of lighter $\mathrm{O}^{16}$.

Prior to DSDP Leg 23, some deep sediment and rock samples had been obtained from drilling in the Red Sea area, but few results have been reported. The purpose of this paper is to summarize the sedimentary studies made on Leg 23 and to compare them with previously collected material.

\section{PREVIOUS DRILLING INFORMATION}

At least 20 wells have been drilled in the Red Sea. Well data have been given by Ahmed (1972) for the eastern Red Sea; Gillmann (1968), Mason and Moore (1970), and Lowell and Genik (1972) for Ethiopia; and Carella and Scarpa (1962) for part of the Sudanese coast. Summaries of these well data have been presented by Ross and Schlee (in press) and Coleman (this volume), and much of the material presented in this section is from these two papers.

Wells drilled around the edge of the Red Sea basin (Figure 1) generally reach evaporites of Miocene and younger age. Three wells (Bargan 1, Bargan 2, and Yuba 1) in the northern corner of the Red Sea did not hit any evaporites, but bottomed in granite. However, El-Morgan 1 in the Gulf of Suez penetrated 728 meters of evaporites. Basalt basement was reached in two wells along the Sudanese coast. Most of the wells ended in Tertiary sedimentary rocks. Generally, the main sequence pene-

\footnotetext{
${ }^{1}$ Woods Hole Contribution No. 3168.
}

trated is the Miocene evaporites (Frazier, 1970; Lowell and Genik, 1972; Ahmed, 1972) with over $3.8 \mathrm{~km}$ penetration in a diapiric area adjacent to the Dahlac Islands (off Ethiopia) and $3.6 \mathrm{~km}$ found overlying basalt off southern Sudan. On the western side of the Red Sea over $1 \mathrm{~km}$ of evaporites was found near the coast of southern Saudi Arabia (Gillmann, 1968). Correlations between wells, even fairly closely spaced ones, generally show marked changes in thickness (Carella and Scarpa, 1962), probably due, in part, to salt flowage (Frazier, 1970) or erosional pinch-out along angular unconformities (Ross and Schlee, in press). Most of the wells show unconformities within the Miocene section as well as within the post-Miocene sections. Continuous seismic reflection profiles also show truncations of reflectors in the section above reflector S (shown by Leg 23 drillings to be the top of the Miocene evaporite section), indicating Pliocene-Pleistocene unconformities.

The general absence of Oligocene marine sediments in the Red Sea area has led some to suggest that the basin was a topographic high during this time (Gass, 1970; Swartz and Arden, 1960). Eocene transgressive marine deposits have been mapped in northern Sinai and Egypt (Coleman, this volume), but they or older rocks rarely are detected in any of the drillings.

\section{LEG 23B DRILLINGS}

During Leg 23B, six sites were drilled in the Red Sea. Details of the individual holes and their specific aspects can be found within the other chapters of this Initial Report. We briefly report here a summary of the major sedimentary findings at each site before presenting a description of the main sediment types.

\section{Site 225}

This site was drilled on the seaward edge of the main trough about 10 miles to the east of the Atlantis II Deep. It was drilled and continuously cored to a depth of 230 meters (Figure 2). The hole terminated 54 meters into a Late Miocene evaporite sequence. Four distinct sedimentary units were penetrated:

Unit I-Gray foram-bearing micarb-rich ${ }^{2}$ detrital clay silt nanno ooze and chalk that ranged in age from Early Pliocene to Late Pleistocene. The total thickness of this unit is 112 meters. Its sedimentation rate ranged from 100 $\mathrm{m} / \mathrm{m} . \mathrm{y}$. at the base of the unit to $70 \mathrm{~m} / \mathrm{m}$.y. in the Late Pleistocene. A possible unconformity separates the Pliocene from the Pleistocene sequence.

\footnotetext{
${ }^{2}$ The term micarb refers to microcrystalline carbonate particles.
} 


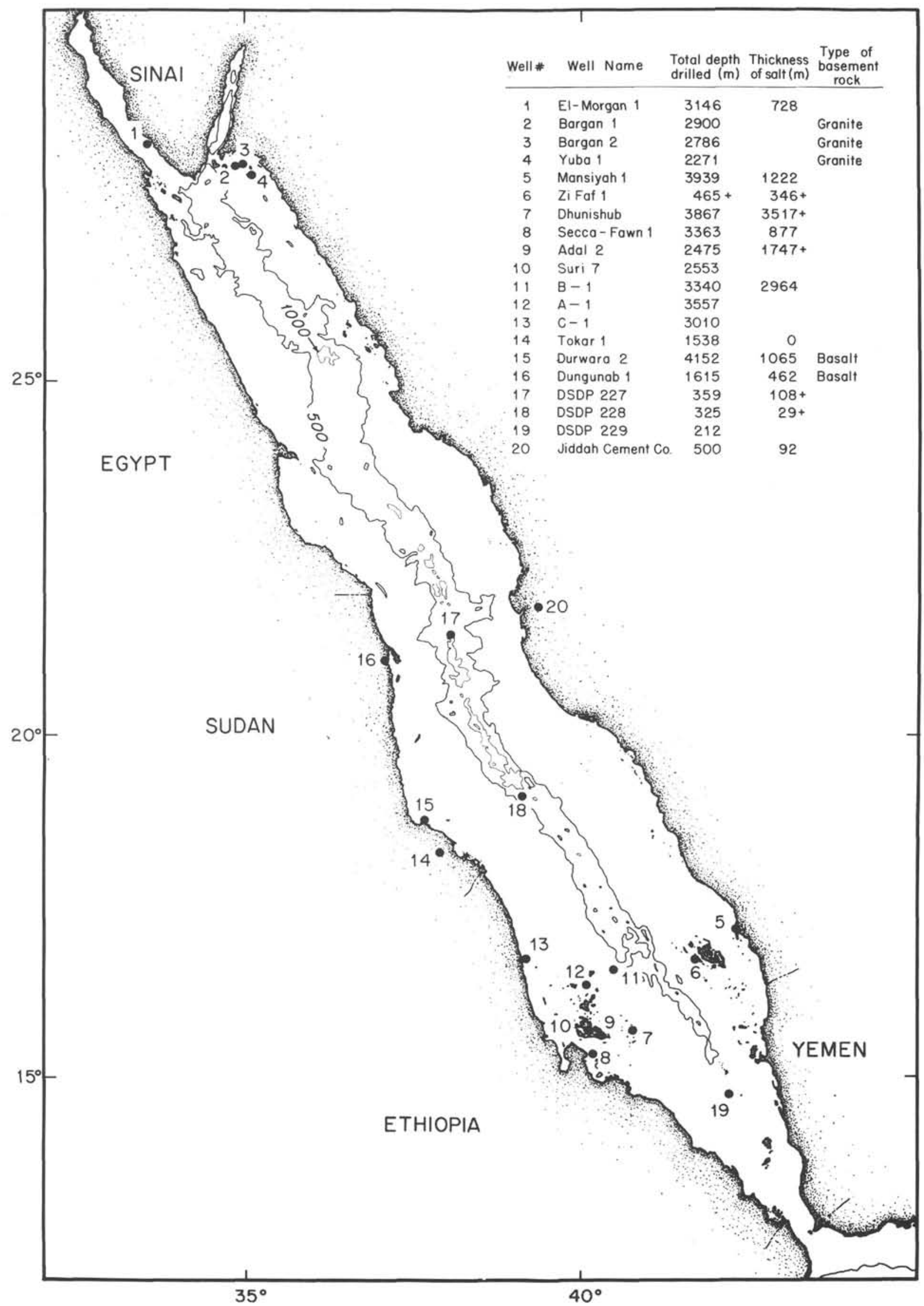

Figure 1. Locations of DSDP and other drilling sites in the Red Sea (from Ross and Schlee, in press). 


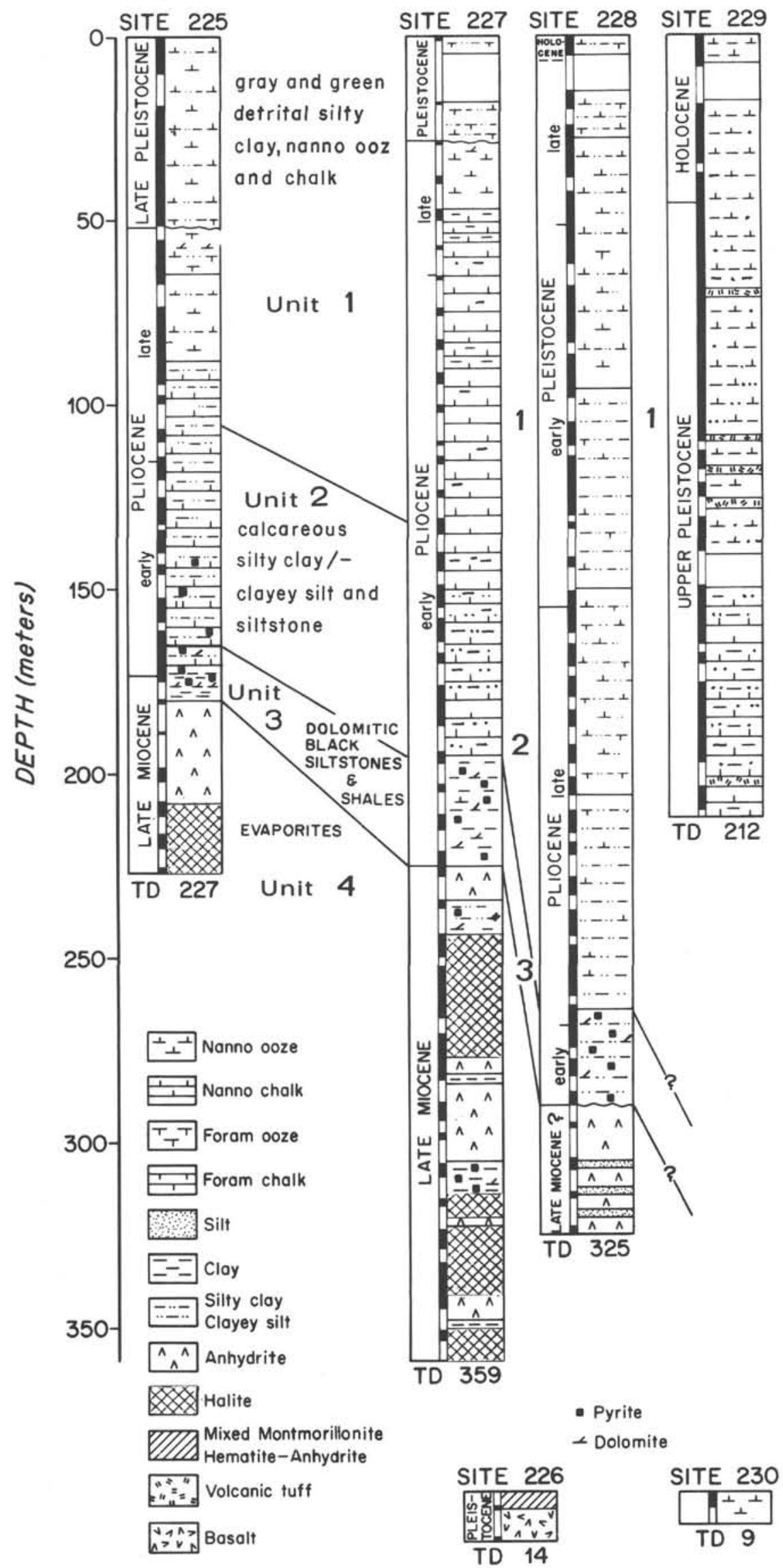

Figure 2. General stratigraphy of sediments cored during Leg 23B. 
Unit II-Gray micarb-rich nanno detrital silty claystone of Early Pliocene age. Total thickness is 55 meters and the sedimentation rate was about $20 \mathrm{~m} / \mathrm{m} . \mathrm{y}$.

Unit III-Dark gray dolomitic slity claystone of Early Pliocene or Late Miocene age. Total thickness is 9 meters and the sedimentation rate was about $20 \mathrm{~m} / \mathrm{m}$.y.

Unit IV-Lithified anhydrite and halite sequence with occasional black shale layers of presumed Late Miocene age.

Lithologic and paleontologic evidence suggest that unit IV was deposited in shallow, restricted evaporite conditions which gradually changed to more open conditions in the Pliocene and Pleistocene during the deposition of units III, II, and I. The dark muds and shales above the evaporite sequence are occasionally enriched with iron, vanadium, and molybdenum (see Manheim, this volume). Shales within the evaporite sequences are also enriched with vanadium and molybdenum but also contain considerable copper. Reducing conditions are indicated during the deposition of unit IV by the finding of relatively high amounts of organic matter, pyrite, and shales within the evaporite sequence.

\section{Site 226}

This site was drilled in the central part of the axial trough in an area having high bottom water temperature and salinity, the so-called Atlantis II Deep located within the hot brine area of the Red Sea. Only two sediment cores were obtained and these had sediments similar to those obtained previously from the hot brine area (Bischoff, 1969). A mixed montmorillonite, anhydrite, and goethitehematite mixture of sediments was obtained having an approximate thickness of 5 meters and being probably of Late Quaternary age. A second core which penetrated to a depth of 9 meters below the first one (i.e., $14 \mathrm{~m}$ total depth) contained fresh basalt fragments. These basalts showed no indication of any chemical reaction with the hot solutions and are similar to basalts described from oceanic spreading centers (Chase, 1969). It is conceivable that heavy metal-rich sediments can occur below the basalt; however, we were unable to penetrate the basalt layer during the drilling.

\section{Site 227}

This site was drilled on the edge of the axial trough about 3 miles east of Site 226 and the Atlantis II Deep. Drilling continued to a subsurface depth of 350 meters and ended 133 meters into the Late Miocene evaporite sequences. As at Site 225, four distinct and similar lithologic units were identified.

Unit I-Gray micarb-rich detrital clay nanno ooze and chalk which was 131 meters thick. Two unconformities are suggested at this site, one in the early Pliocene and the other at the Plio-Pleistocene boundary. Sedimentation rate above the Early Pliocene unconformity is $90-105 \mathrm{~m} / \mathrm{m} . \mathrm{y}$. and below it to unit III is $100-130 \mathrm{~m} / \mathrm{m}$.y.? This unit ranges in age from Late Pleistocene to Early Pliocene.

Unit II-Gray micarb-rich detrital nanno silty claystone of Early Pliocene age. Total thickness is 63 meters and the sedimentation rate for this unit is between $100-130 \mathrm{~m} / \mathrm{m} . \mathrm{y}$.

Unit III-Dark gray dolomitic silty claystone of Early Pliocene age. Total thickness is 32 meters and the sedimentation rate for this unit is between $100-130 \mathrm{~m} / \mathrm{m} . \mathrm{y}$.
Unit IV-A lithified anhydrite and halite with interbeds of hard, black shale. A total of 133 meters was drilled into this unit before drilling stopped. Bedding planes within the evaporite sequence tend to be fairly steep, having a general dip of between $40-60^{\circ}$. This steep dip could be due to solution collapse, salt flowage, or perhaps to regional deformation in the Red Sea. As at Sites 225 and 228, the dark muds and shales overlying and within the evaporite sequence tend to be occasionally enriched with vanadium, molybdenum, copper, and iror. This enrichment, being so close to the hot brine area, suggests more than a casual relationship and is further discussed in the paper by Manheim (this volume). The general sedimentary sequence, as observed at Site 227, is similar to that at Sites 225 and 228 , and is correlative (Figure 3 ) on the basis of the microfauna (Fleisher, this volume). The interpretation of the sediments is also similar to that of the other two sites, initiating with a Late Miocene evaporite phase in a relatively shallow evaporite basin with some indication of occasional reducing conditions as indicated by high amounts of organic material and pyrite within the black shale layers. The overlying units were deposited in a more open ocean situation with occasional reducing conditions as indicated by black shale layers containing high organic carbon and pyrite content.

\section{Site 228}

This site lay to the south of the previous three sites, but was also drilled near the axial valley of the Red Sea. The hole reached a depth of 322 meters below the sea floor ending 38 meters into an evaporite sequence. As at Sites 225 and 227, four distinct sedimentary units were observed:

Unit I-Gray detrital silt-rich micarb nanno ooze and micarb-rich siltstone having a total thickness of 195 meters. This unit comprised the entire Pleistocene and uppermost Pliocene. A minor unconformity occurs near the Pliocene/ Pleistocene boundary. Sedimentation rates for this unit are $150 \mathrm{~m} / \mathrm{m} . \mathrm{y}$. after the unconformity and increased to 230 $\mathrm{m} / \mathrm{m} . \mathrm{y}$. in the Late Pliocene.

Unit II-Gray micarb siltstone of Late Pliocene age. Total thickness is 55 meters and the deposition rate for this unit is $230 \mathrm{~m} / \mathrm{m} . \mathrm{y}$.

Unit III-Gray-black dolomitic detrital silty claystone ranging from Late to Early Pliocene in age. Total thickness is 37 meters and the sedimentation rate is $230 \mathrm{~m} / \mathrm{m} . \mathrm{y}$. An unconformity separates this unit from unit IV.

Unit IV-A lithified evaporite sequence consisting of anhydrite interbedded with gray and black siltstones similar to those found at Sites 225 and 227.

The sediments found at Site 228 are very similar to those at Sites 225 and 227 with essentially the same lithologies, although at Site 228 no halite beds were reached by the drilling. They may well have existed at a depth further down in the hole. One main difference between Site 228 and the other sites is that the sedimentation rate is considerably higher. This greater thickness of sediment may be due to the site's nearness to a former delta off the Sudanese coast (Coleman, this volume). 


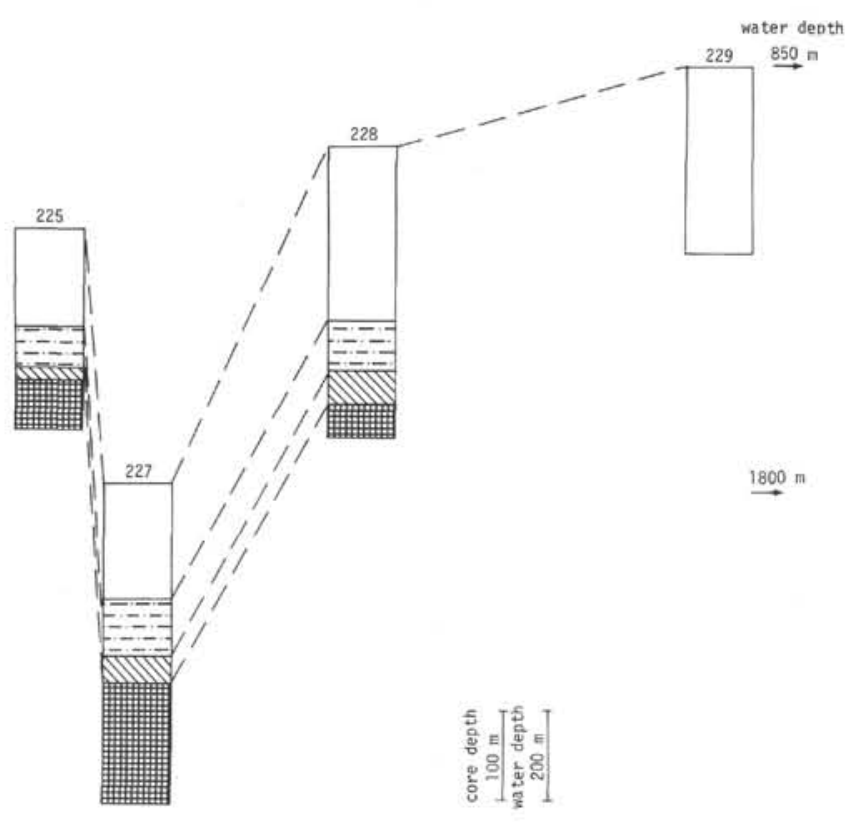

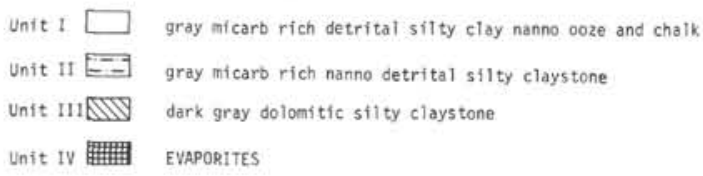

Figure 3. Correlation of the four distinct sedimentological units cored during Leg $23 B$.

Heavy mineral studies of the Pliocene-Pleistocene section at Site 228 suggest derivation from a metamorphic or granitic terrain. Such a sequence of rocks is found in the Pre-Cambrian section of Sudan, and could well have been the source for these sediments.

The sediments in and overlying the evaporite sequence show moderately steep dips suggesting some sort of sediment movement. At this site the presence of halite, although not actually cored, was suggested by the interstitial salinity water gradient. As with Sites 225 and 227 , some of the siltstones were enriched with heavy metals. One had a very high boron content and about $1 \%$ manganese as well as being enriched with zinc, copper, and iron.

The interpretation of the sedimentary record at Site 228 is similar to that of the other two sites, that is, deposition in a relatively shallow environment gradually changing to open water conditions. The unconformities here and at the other sites are indicative of tectonic movements or interruptions in sedimentation. It is possible that some of the unconformities could be due to salt tectonics. Most of the Early Pliocene section is missing at this site, and a gap of as much as 1 million years or more may be present between the presumably Miocene evaporites and the overlying sediments. The hiatus could be due to local salt tectonics.

\section{Site 229}

This site was located further to the south in the Red Sea and lay in a small basin south of the Zubayer Islands. The site penetrated 212 meters of a Late Quaternary (Holocene) and Late Pleistocene sediment. There is only one lithologic unit here, the sediment being basically a calcareous ooze with detrital silt and clay present in relatively small quantities. The sedimentation rate is extremely high for this unit-over $1,000 \mathrm{~m} / \mathrm{m} . \mathrm{y}$. However, due to the lack of reliable horizons, there is some uncertainty in actually determining the sedimentation rate at this site.

Based on the salinity of interstitial pore waters, which accurately predicted the evaporites at the previous sites, one would have to conlcude that salt does not underlie this site since the interstitial waters did not show their typical increase with depth indicative of underlying evaporites.

Concerning the origin of these sediments, it seems probable that much of the material may have been carried in from the surrounding areas by strong bottom currents which exist in this area. Other sediments may have come in from slumping. Occasionally volcanic tuff layers were encountered which suggests some local volcanic activity.

\section{Site 230}

This site was on the western side of the axial trough at the base of a relatively steep slope. Only a single core was obtained at this site. The core consisted of a Late Quaternary greenish carbonate nanno ooze with pteropod, foraminifera, nannofossil casts, and some fine carbonate particles and zeolite. There were also some thin streaks of volcanic ash in the core, again suggesting local volcanic activity, possibly from the nearby young volcanoes of Jebel Atair and Zubayer Islands. Although we only penetrated 9 meters, the interstitial waters of this short core had a salinity of $59 \%$ which was a $50 \%$ increase over the normal salinity of the Red Sea suggesting that halite may be present at this site. This observation is consistent with the observation of the seismic reflector (reflector S) at this rate which generally indicates the top of the evaporite sequence.

\section{CONSTITUENTS OF SEDIMENTS OBTAINED BY LEG 23B DRILLING}

As a result of shipboard and laboratory work, the various major constituents can be identified (Table 1).

\section{Biogenic Constituents}

The Holocene, Pleistocene, and part of the Pliocene sediments recovered during Leg 23B drilling are predominantly pelagic carbonate ooze and chalk. Most of these oozes and chalks are mixtures of calcareous nannofossils with smaller amounts of foraminifera (Figure 4) and pteropods. The nannofossil content ranges from about $20 \%$ to $70 \%$. It is noteworthy that in the dark sediment layers which are enriched in organic material and pyrite the nannofossils seem to be less recrystallized than in the light gray sediments. Small carbonate grains of uncertain origin are also very abundant in this sediment sequence. They are described as "micarb particles." These particles are thought to be the result of coccolith shield fragmentation and recrystallization. Such processes have been shown to occur in deep-sea sediments (Lancelot et al., 1972; Beall and Fisher, 1969; Matter, this volume).

Foraminifera and pteropods are concentrated in the coarser sediment layers where they range up to $20 \%$. They are the dominant constituents in the sand-size sediments of Site 227, Core 1. 
TABLE 1

Major Sedimentary Constituents of Red Sea Sediments

Biogenic Constituents

Nannofossils, foraminifera, pteropods, siliceous fossils, other fossils

\section{Volcanogenic Constituents}

Tuffites, volcanic ash, montmorillonite, cristobalite, zeolites as devitrification products of volcanic glass

\section{Terrigenous Constituents}

Quartz, feldspar, rock fragments, mica, heavy minerals, clay minerals

\section{Authigenic Minerals}

Sulfide minerals, aragonite, Mg-calcite, protodolomite, dolomite, quartz, chalcedony

Evaporitic Minerals

Magnesite, gypsum, anhydrite, halite, polyhalite

Brine Precipitates

Fe-montmorillonite, goethite, hematite, siderite, rhodochrosite, pyrite, sphalerite, anhydrite

Siliceous fossils are generally rare in the Red Sea sediments. Sponge spicules are observed in Hole 229A in Cores 1 through 7. At Site 225, Core 19 pyritized Radiolaria, diatoms, and silicoflagellates occur. Diatoms are also present in Site 225, Core 25. Very small amounts of otoliths, micropelecypods, and fish teeth are found in the cores, mainly at Site 229.

\section{Volcanogenic Constituents}

The volcanic glass and ash layers frequently found demonstrate that volcanic activity occurred throughout the time interval (Miocene-Recent) represented by the cores. A lithified tuffite was found in Hole 229A, Cores 8 and 17 and Hole 229, Core 6. This tuffite (Figure 5) is characterized by abundant glass particles of various sizes (0.01-0.1 mm), by pumice fragments with vesicles, volcanic rock fragments, fragments of feldspar (labradorite and sanidine), and pyroxene. All these particles are cemented by calcite. The pyroxene is often replaced by calcite. Biogenic components are also common in the tuffitic sediments. The vesicles of the tests are either empty or filled with calcite or analcite (Stoffers and Müller, this volume).

Montmorillonite generally dominates the fine fraction of the Red Sea sediments. The question whether the montmorillonite is of detrital origin or an in situ alteration product of volcanic material is not easy to answer. The association with zeolites and volcanic material suggests that most of the montmorillonite formed in situ by the devitrification of volcanic material as described by several authors (Nayudu 1964; Biscaye, 1965). This particularly applies to some of the black shales which are intercalated in

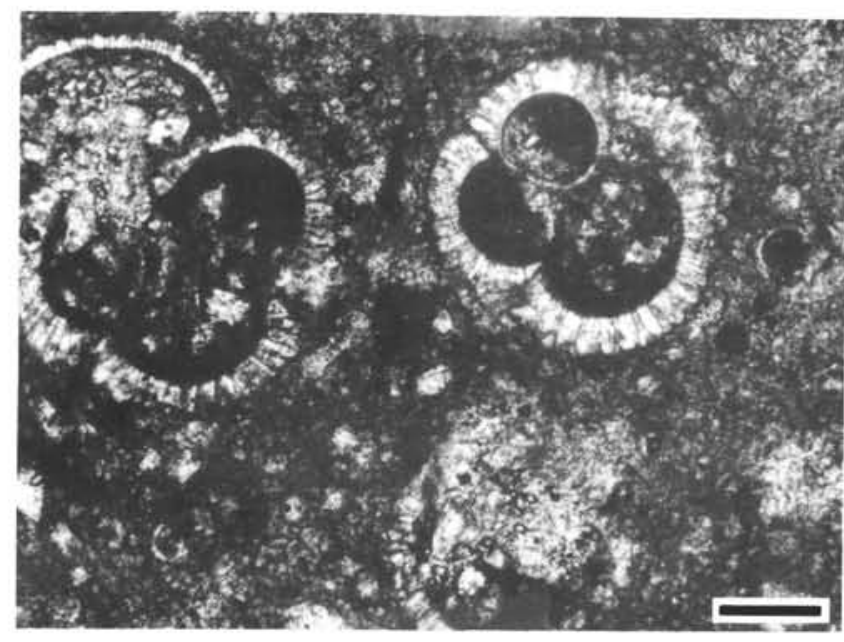

Figure 4. Pleistocene Red Sea sediment (227-3-1, $27 \mathrm{~cm})$ with Globigerina spp. and some small dolomite rhombs. Scale bar represents $0.1 \mathrm{~mm}$.

the evaporitic sequence. These shales are mainly composed of montmorillonite.

Disordered cristobalite (Figure 6) in the form of small spherules $(5-10 \mu)$ is the main constituent $>50 \%)$ in the black shales of the evaporitic section of Site 225, Core 26 and Site 227, Core 31, CC and Core 36. This disordered cristobalite is an irregular structural interstratification of cristobalite layers with tridymite layers described as lussatite (Matter, this volume; von Rad and Rösch, 1972). The silica might come from the dissolution and recrystallization of siliceous organisms in high $p \mathrm{H}$ conditions or from the decomposition of volcanic ash in waters of high ionic strength.

Zeolites are common constituents in distinct intervals in the sedimentary sequence. Analcite, which locally occurs in small amounts scattered throughout the cores, is abundant in the Lower Pliocene section of Sites 225 and 227 ranging up to more than $30 \%$. In the tuffitic section of Site 229 , Core $8 \mathrm{~A}$, analcite is found as a secondary filling in glassy

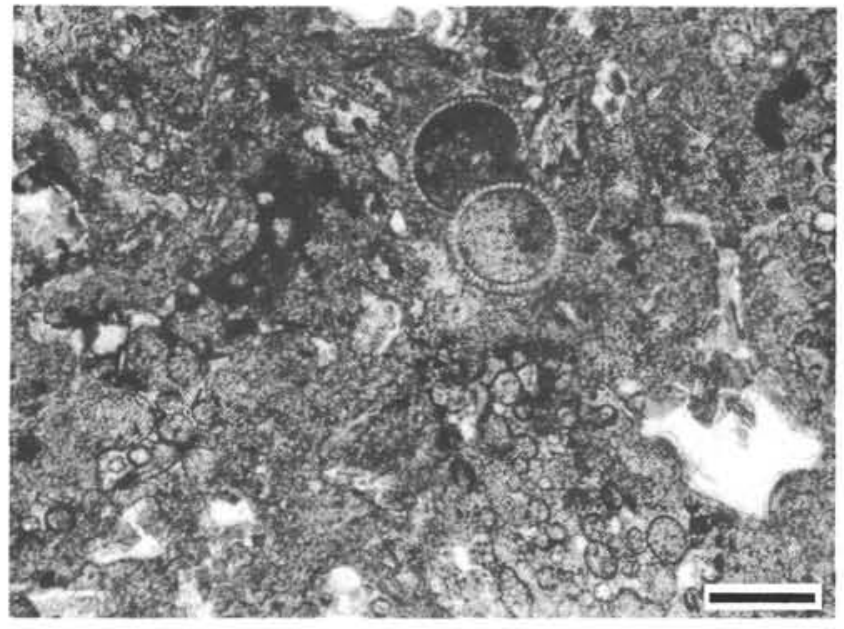

Figure 5. Pleistocene tuffitic sediment (229A-8-2) showing glass and pumice fragments with filled vesicles and biogenic constituents. Scale bar represents $0.4 \mathrm{~mm}$. 

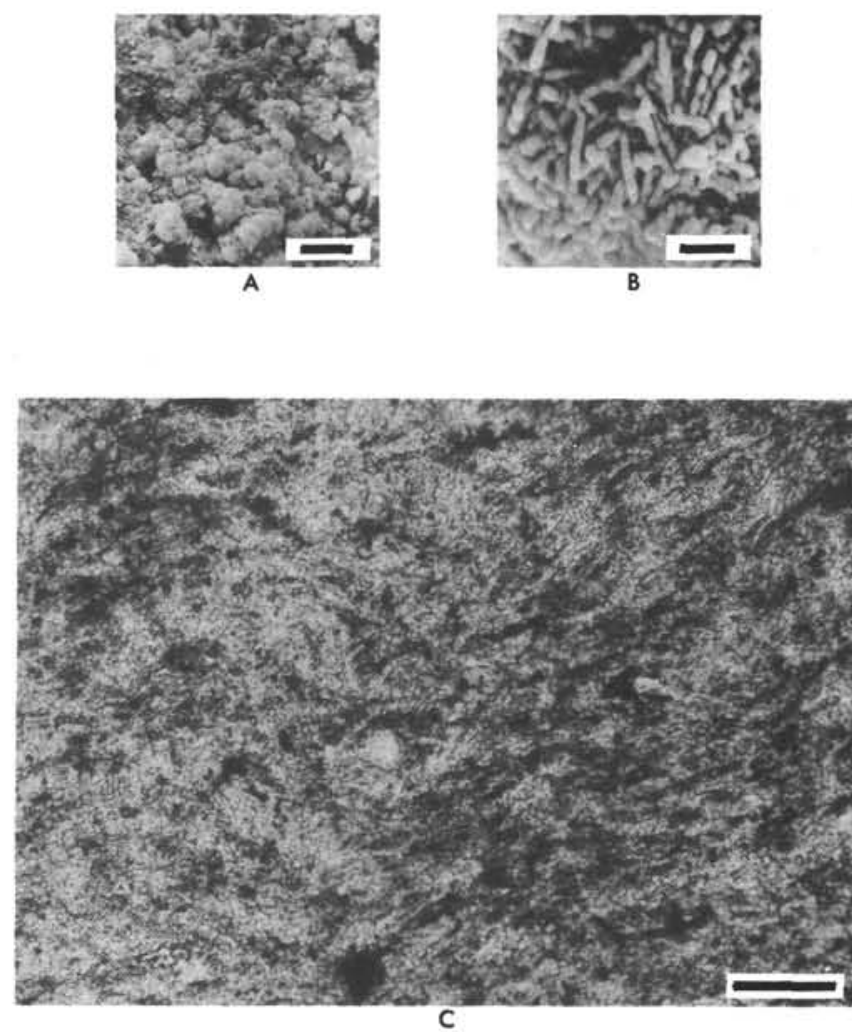

Figure 6. (227-36-2). (a \& b) Electronmicrographs of cristobalitic sediments showing typical 5-10 $\mu$ large spherules. (a) Scale bar represents $\sim 0.02 \mathrm{~mm}$; (b) Scale bar represents $\sim 0.001 \mathrm{~mm}$; (c) Thin sections of microcrystalline cristobalite finely laminated by opaque material. Scale bar represents $0.1 \mathrm{~mm}$.

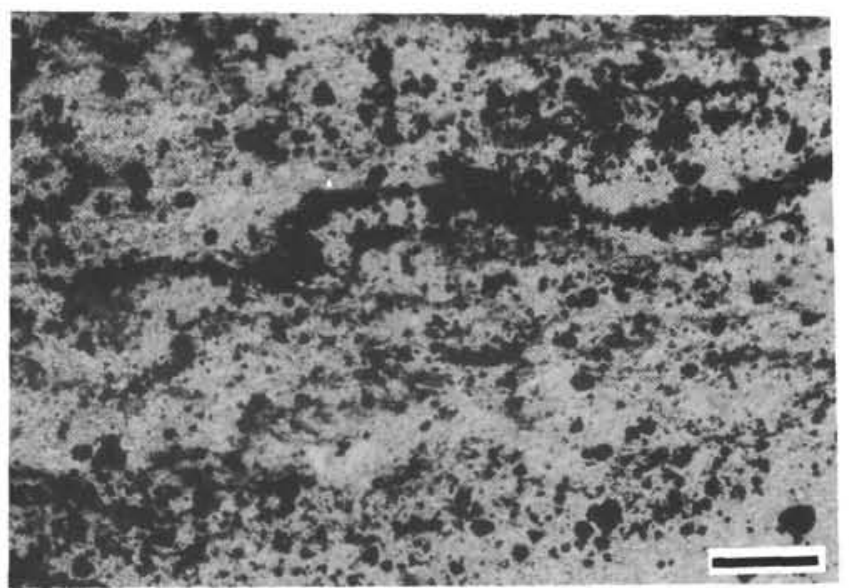

Figure 7. Sphalerite in anhydrite-shale matrix (228-39-7). Scale bar represents $0.4 \mathrm{~mm}$.

vesicles. Analcite can be formed by the interaction of hypersaline water with clay minerals (Millot, 1970; Keller, 1952) or by halmyrolytic devitrification of volcanic material (Norin, 1953; Müller, 1961a). A possible volcanic origin of the Red Sea analcite due to transformation of pyroclastic material is suggested by the association with volcanic glass and montmorillonitic clays. One sample of Site 225 , Core 15 contains abundant phillipsite and small amounts of clinoptilolite. No phillipsite could be detected in any other samples studied. Clinoptilolite occurs in various amounts $(5 \%-20 \%)$ in the silty clays of Site 227 , Cores 17 to 25 and in Site 225, Cores 19 to 23 . Clinoptilolite and phillipsite are fairly common in marine sediments (Bonatti, 1963; Arrhenius, 1963; Biscaye, 1965; Bonatti and Joensuu, 1968; and Hathaway et al., 1970).

The occurrence of zeolites in certain zones and the presence of volcanic material favors the idea of alteration of volcanic detritus. The alteration to phillipsite or clinoptilolite largely depends on the composition of the original ash rather than on the environment of deposition.

\section{Terrigenous Constituents}

In general, detrital components increase with core depth reaching their highest values in the Pliocene section.

The feldspars are the most abundant terrigenous components, the quartz/feldspar ratios vary between 0.4 and 1.2 with an average of about 0.7 . Plagioclase is the most abundant feldspar ranging up to $32 \%$ in the bulk mineralogy of Site 228. There are smaller amounts of K-feldspar, i.e., microcline (up to $11 \%$ in Site 228, Core 5) and sanidine. In contrast to the plagioclase and microcline, which are thought to be terrigenous due to their close association with quartz, the occurrence of sanidine in the lithified tuffs of Site 229 suggests either formation from altered glass during diagenesis, or a direct crystallization during submarine volcanism (von Rad and Rösch, 1972).

Quartz is ubiquitous in the Red Sea sediment cores with the exception of the evaporitic sequence and varies from $3 \%$ to $25 \%$ in the bulk samples. In the sand fraction of sediments from Site 228 the quartz content is as high as $40 \%$. The highest values for quartz are found in the sediments of Sites 228 and 229.

Brown to green unaltered biotite and muscovite are abundant in the silt and sand fractions of Site 228. In these fractions the heavy mineral content ranges up to $15 \%$ with green and brown hornblende being the dominant mineral, followed by epidote, garnet, sillimanite, staurolite, sphene, rutile, zircon, and tourmaline.

Rock fragments are very rare within the silty and sandy sediments of Site 228 . The only fragments which could be identified are derived from metamorphic rocks (mainly gneissic fragments and some mica schists).

Dolomite rhombs are common $(2 \%-20 \%)$ in part of the Pliocene, Pleistocene, and Holocene sediments of all sites. In general, high dolomite values correspond with high amounts of the detrital minerals; suggesting a terrigenous origin for the dolomite.

Montmorillonite, palygorskite, illite, kaolinite, and chlorite, together with smaller amounts of quartz, feldspar, and zeolites were detected in the clay fraction of the Red Sea sediments. The highest values for illite $(15 \%-40 \%)$, kaolinite $(10 \%-30 \%)$, and chlorite $(7 \%-16 \%)$ are found in the terrigenous sediments of Site 228 which clearly indicates their detrital origin.

Palygorskite is abundant in the upper cores of Early Pliocene age, in the Late Pliocene, and in the Pleistocene section. Hardly any palygorskite occurs in the lower cores of the Early Pliocene sequence. Some greenish-white samples from the fractured evaporitic section of Site 228 
have palygorskite as the dominant constituent $(>80 \%)$. Palygorskite has been reported by several authors to be a constituent of marine sediments (Hathaway and Sachs, 1965; Bonatti and Joensuu, 1968). More recently, results from the Deep Sea Drilling Project have shown that palygorskite is often very common in ocean sediments (e.g., Peterson et al., 1970; von Rad and Rösch, 1972). Palygorskite was described by Heezen et al. (1965) in sediments from the southern Red Sea. Most of the authors explain the occurrence of palygorskite by diagenetic formation from degraded montmorillonitic clays by magnesium-rich solutions. The palygorskite in the upper sequence of the Red Sea cores, however, does not show any relationship to the presence of zeolites or pyroclastic material. This strongly suggests a continental source for the palygorskite. This idea is further supported by the widespread occurrence of palygorskite in Tertiary and Quaternary sediments of Southern Arabia (Müller, 1961b).

The palygorskite in the fractured evaporitic section, by contrast, is thought to be precipitated directly from magnesium-rich brines in a hypersaline environment (Millot, 1970 ) or to be derived from the alteration of pyroclastic material.

\section{Authigenic Minerals}

Pyrite is ubiquitous not only in the dark sediments but also in light gray sediments. It is found in the form of irregular grains, as cast and replacement of fossils and burrows. Large concretions (1-3 cm thick) are present in the Pleistocene section of Sites 225 and 227. Within the black carbonaceous interlayers in the Early Pliocene and Pleistocene section pyrite is abundant (5\%-10\%), reflecting the reducing environment.

Sphalerite is found in small amounts at Site 227 , Cores 3 and 13. Euhedral sphalerite up to $5 \%$ occurs in the fractured and brecciated shale-anhydrite sequence of Site 228 (Figure 7).

In the Pleistocene section of Sites 225, 227, 228, and 229 lithified layers occur which are mainly composed of aragonite, some of $\mathrm{Mg}$-calcite (Figure 8a). These lithified layers are described in great detail by Herman (1965), Gevirtz and Friedman (1966), and Milliman et al. (1969). Most of the recognizable fossils are aragonitic pteropods which are recrystallized and filled with aragonite needles. Fibrous and drusy aragonite crystals radiate syntaxically from the fossils (Figure $8 \mathrm{~b}$ ). These fragments contain strontium on the order of $5000 \mathrm{ppm}$. The high strontium values are indicative of authigenic aragonite. Because of the drilling procedure, these hard layers were completely mixed up with lutite layers, and no correlation was possible.

High Mg-calcite (up to $60 \%$ ) with 10 to 14 mol-\% magnesium is very abundant in the Pleistocene sequence of Sites 225, 228, and 229. No Mg-calcite was detected at Site 227. Shallow water material has contributed very little to the Red Sea deep-sea sediments. Scarce benthic foraminifera are the only visible contributors of $\mathrm{Mg}$-calcite to the Red Sea sediments. This suggests that the Mg-calcite in the Red Sea lutites is of inorganic origin (Milliman et al., 1969; Gevirtz and Friedman, 1966), probably similar to the Mg-calcite in the lithified fragments.

Ca-dolomite (up to 9 mol-\% excess calcium) and stoichiometric dolomite were encountered in the black
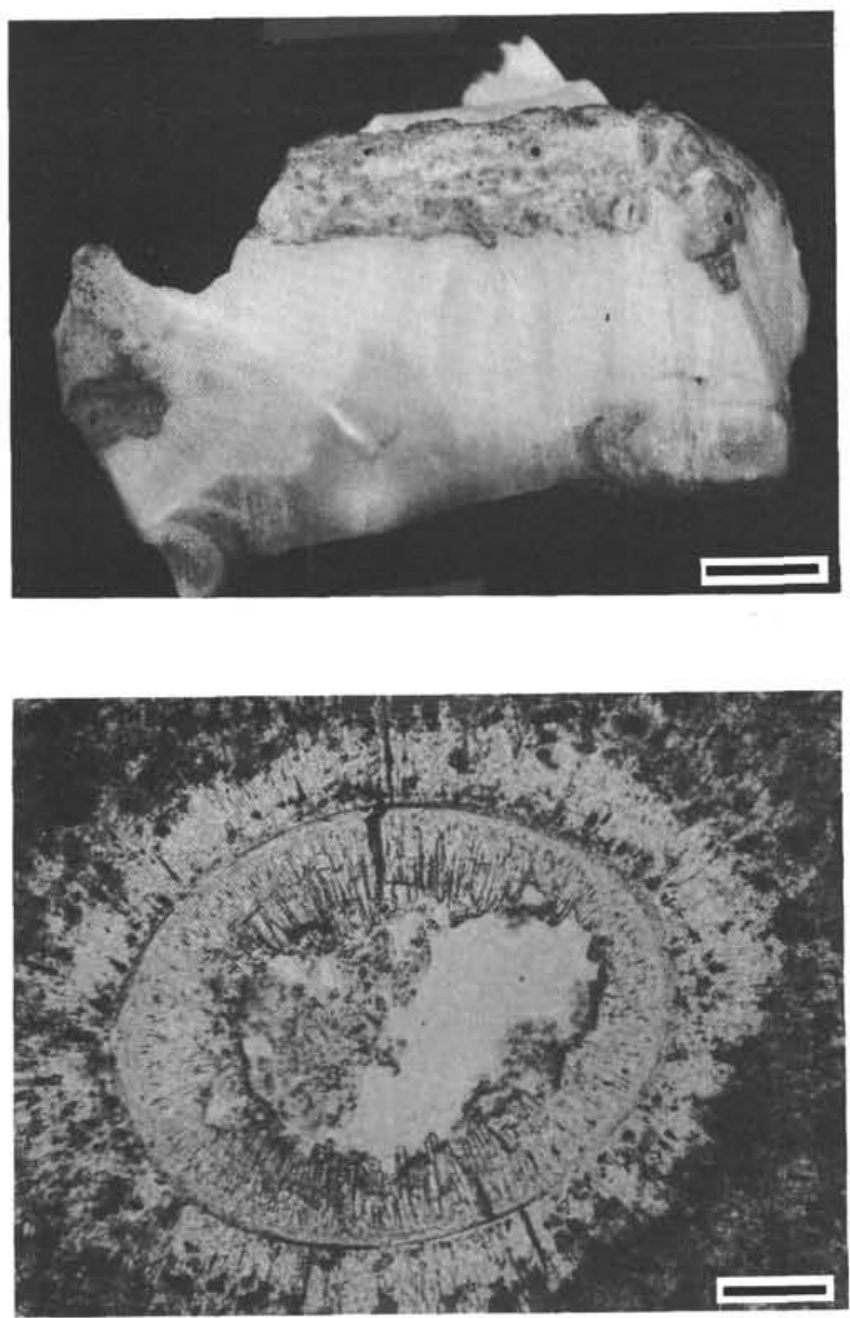

Figure 8. (a) Photographed hard layer (227-3-1) showing clear white fibrious aragonite topped by dark material composed of pteropods. Scale bar represents $5 \mathrm{~mm}$. (b) Lithified aragonitic layer (227-3-1, 5-9 cm). Aragonitic pteropods are recrystallized and filled with aragonite needles. Scale bar represents $0.1 \mathrm{~mm}$.

sediments above the anhydrite-halite sequence at Site 225, Cores 21-23; Site 227, Cores 26 to 29; and Site 228, Cores 30 to 35 . The dolomite content ranges between $20 \%$ and $80 \%$. In general, the dolomite is very fine grained (Figure 9). The grains are hypidiotopic to idiotopic and often contain darker nuclei. Smaller amounts of dolomite occur within the anhydrites. There the dolomites are formed as tails or single grains or as clusters of aggregates floating in the anhydrite.

Idiomorphic quartz crystals randomly occur within the anhydrites (Figure 10). They are very abundant in 227-36-3. The quartz crystals which often grow together parallel to the main axis frequently contain inclusions of anhydrite. These inclusions are oriented parallel to the crystal edges due to rhythmic growth of the quartz crystals. According to Grimm (1962) the authigenic quartz formation in evaporites is caused by the precipitation of silicic acid and is assumed to be early diagenetic.

Sheave-like, partly radiating bundles of length-slow fibers of quartzine were found in the brecciated black 


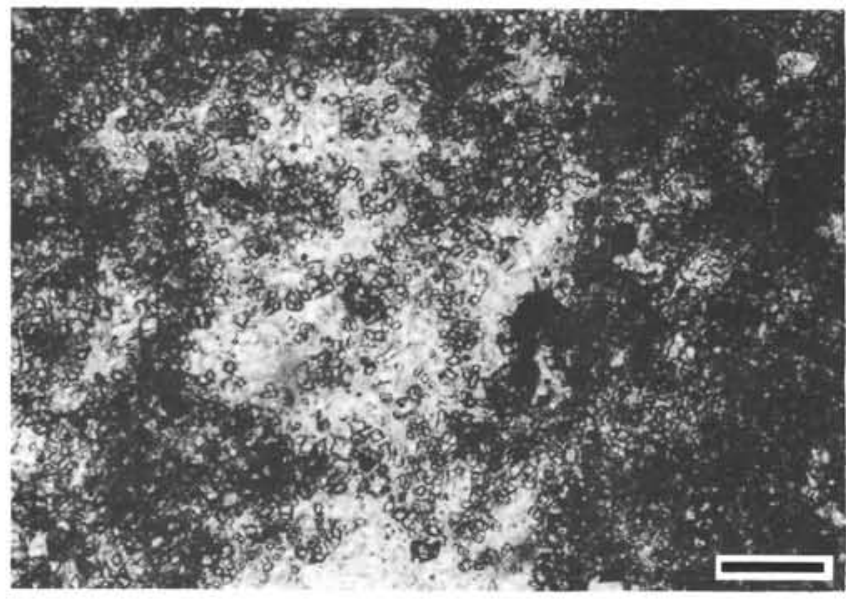

Figure 9. Fine-grained dolomite $(225-21-1,125 \mathrm{~cm})$. Scale bar represents $0.1 \mathrm{~mm}$.

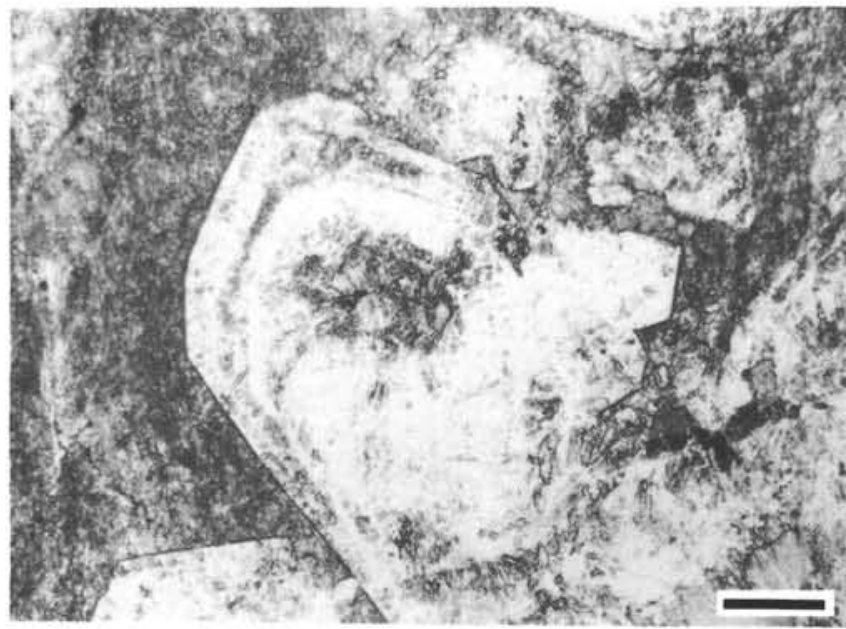

Figure 10. Authigenic quartz with oriented anhydrite inclusions in fine crystalline anhydrite matrix (227-36-3). Scale bar represents $1 \mathrm{~mm}$.

shales of Site 227,'Core 31 (Figure 11). According to Folk and Pittman (1971), quartzine is characteristic of a silification in highly basic or sulfate-rich environments.

\section{Evaporitic Minerals}

Anhydrite occurs at Site 225, Cores 24 to 29 ; Site 227, Cores 30,35 to 39,41 , and 44 ; Site 228 Cores $35,36,37$, and 39. At Site 228 most of the anhydrite is brecciated with a matrix of siltstone. At Sites 225 and 227, two general types of anhydrite occur (Figure 12c, d). The upper part of the evaporitic sequence is a fine wavy laminated anhydrite. The laminae of alternating white and grayish color are about $3 \mathrm{~mm}$ thick. In the lower part of the section the anhydrite is nodular. The nodules (1-3 cm in diameter) of white anhydrite are separated by thin greenish-gray seams which mainly consist of dolomite and opaque, probably organic-rich, material.

Halite was encountered at Site 225 , Cores 27 to 29 and Site 227 Cores 30,32 to 35,41 to 43 , and 45 . The contact between anhydrite and halite is very sharp (Figure 12a).

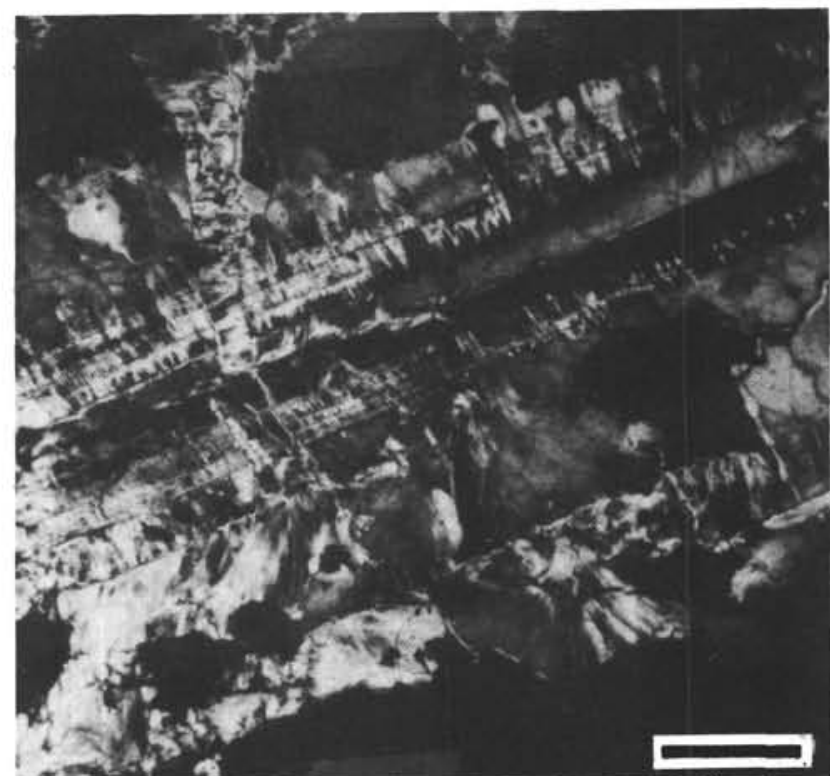

Figure 11. Length of slow fibers of quartzine in cristobalitic shale (227-31; CC). Crossed nicols. Scale bar represents $0.1 \mathrm{~mm}$.

Due to solution by water during coring, the halite cores are thinned. The less-soluble material (mostly anhydrite) within the halite therefore forms very distinct $0.5-1-\mathrm{cm}$-thick layers (Figure 12b). Alteration of pure white with dirty gray halite in intervals of approximately $3-7 \mathrm{~cm}$ is typical of the whole halite sequence. The cloudy appearance of the gray halite is due to scattered brine inclusions (Figure 13).

Magnesite was detected by X-ray analyses in samples from Site 227, Core 36 and in the lower part of Core 35. The very fine crystalline magnesite $(0.003-0.007 \mathrm{~mm})$ occurs as clusters or streaks within the anhydrite. Frequently, magnesite forms ring-like aggregates which surround a single magnesite or pyrite grain. The occurrence of magnesite is related to progressive concentration of the brine during which the heavier magnesium chloride solution accumulated in the deepest part of the basin. The fine-grained magnesite is considered to be early diagenetic.

Traces of gypsum $(2 \%-10 \%)$ were detected by X-ray diffraction as well as by petrographic microscope in samples of Site 228, Core 39 and Site 227, Core 40 (Figure 14). No gypsum was found in any other cores of the evaporitic section. However, some of the anhydrites show forms which might indicate gypsum pseudomorphs (Stoffers and Kühn, this volume).

Very fine-grained polyhalite (up to $25 \%$ ) was found within the halite sequence at Site 225 , Core 29 and Site 227, Cores 32, 33, and 45. The polyhalite (Figure 15) fills pore spaces between halite crystals and is thought to be an early diagenetic mineral (Holser, 1966).

\section{Brine Precipitates}

Due to coring difficulties, only two cores were recovered at Site 226 in the Atlantis II Deep. The 14 meters of heavy metal-rich sediments together with chips and fragments of basalt were intensely disturbed. Therefore, no distinction of the different brine facies as described by Bischoff (1969) was possible. 

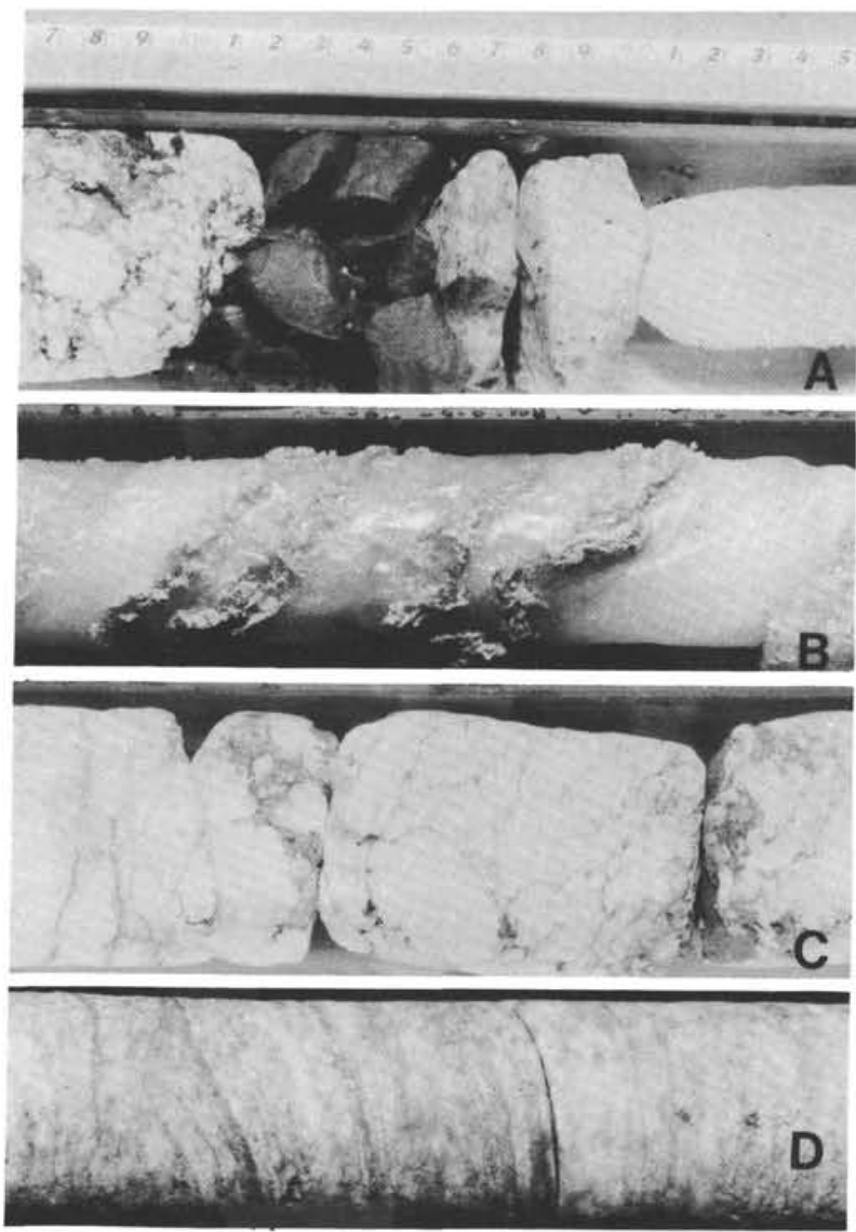

Figure 12. Typical structures of Red Sea evaporites encountered on Leg 23B. (a) White halite, nodular anhydrite, and intercalated montmorillonite black shales (225-29-3). (b) Alternating clear white and cloudy halite with intercalated thin anhydrite layers (227-29-4). (c) Nodular anhydrite $(225-29-2,52-70 \mathrm{~cm})$. (d) fine laminated anhydrite $(227-30-2,3-20 \mathrm{~cm})$.

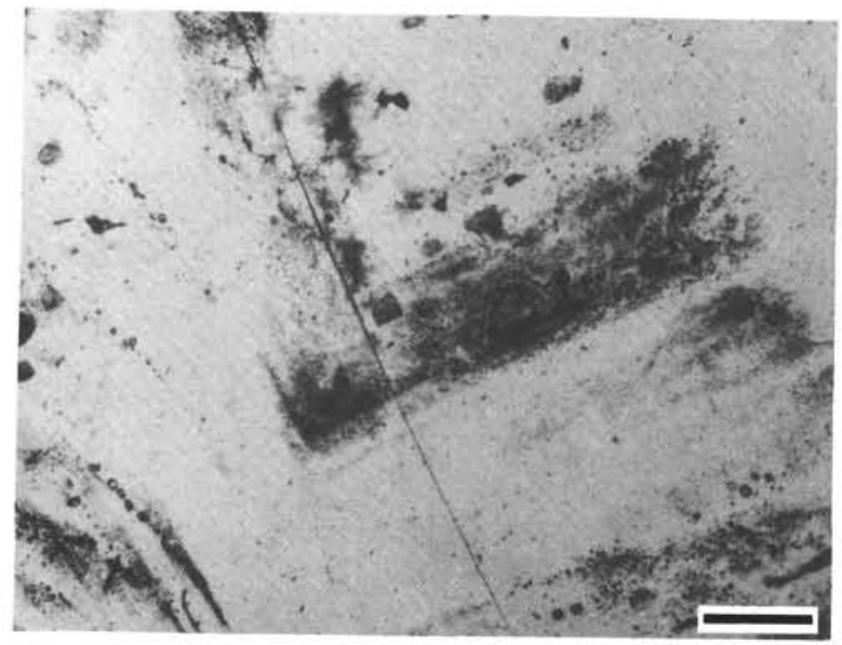

Figure 13. Orientated liquid inclusions in gray halite layers (227-45-1). Scale bar represents $0.1 \mathrm{~mm}$.
The basalt fragments, of deep oceanic tholeiitic character, do not indicate any alteration from the contact with the hot brine. Chemical analyses show no significantly higher values than for ordinary basalts.

Smear slide and X-ray diffraction studies of the heavy metal-rich sediments showed goethite, hematite, $\mathrm{Fe}$-montmorillonite, anhydrite, pyrite, and traces of sideriterhodochrosite, and sphalerite. Therefore, it appears that the cores penetrated through most of the different brine facies described by Bischoff (1969).

The dioctohedral montmorillonite has a $\mathrm{d}_{060}$-spacing of about 1.51 which suggests that besides nontronite $\left(\mathrm{d}_{060}\right.$ 1.52 ), another smectite mineral has to be present. The unique character of the dark brown to greenish-black Fe-montmorillonite in the Atlantis II Deep was noted by Miller et al. (1966) and Bischoff (1969). Detailed investigations (Bischoff, 1972) indicate that the mineral is intermediate in composition between nontronite and a trioctahedral ferrous-iron end member.

Goethite and hematite occur as transparent yellowbrown to reddish aggregates $5-30 \mu$ in diameter. The goethite is very poorly crystalline. Most of the iron occurs as amorphous material. Sphalerite and siderite-rhodochrosite were only detected by X-ray diffraction techniques.

The heavy metal deposits in the hot brine area are thought to be precipitated as solids out of the overlying brine column. The high metal concentration found in the black shales of Sites 225 and 227 suggests that the sediment sequences surrounding the hot brine deeps can serve as sources of metals for the metal-rich deposits in the deeps (Manheim, this volume).

\section{Texture}

The main textural feature of the Red Sea sediments is their uniformity throughout the cores (Figure 16). Sediments recovered at Sites 225 and 227 are mainly silty clays. Small variations to a higher silt content are closely related to the abundance of foraminifera. Sediments from Sites 228 and 229 are predominantly clayey silts reflecting the greater detrital influence in this area. The sediment texture of all the sites seems to be independent of mineralogy, age, and sedimentation rate. No major differences were found between units I, II, and III.

\section{SEDIMENTARY STRUCTURES}

Banding, bedding, laminations, grading, and bioturbation are the sedimentary structures observed in the Red Sea cores. Banding is characterized by small-scale distinct color alteration without changes in the composition of the sediments. This structure is abundant in the Red Sea cores (e.g., Site 228, Core 6, Section 6). Bedding involves different lithologies as demonstrated by the intercalations of black pyrite and organic carbon-rich sediments in the light gray Plio- and Pleistocene sequence (e.g., 227-14-2,3). Very finely laminated sediments are often found in the Red Sea cores, especially in the more silty sediments and in the black shales intercalated with the evaporites. Clay lumps are very abundant at 227-20-4. These lumps are thought to be associated with redeposition processes by organisms. Grading was noted in the upper cores of the more 


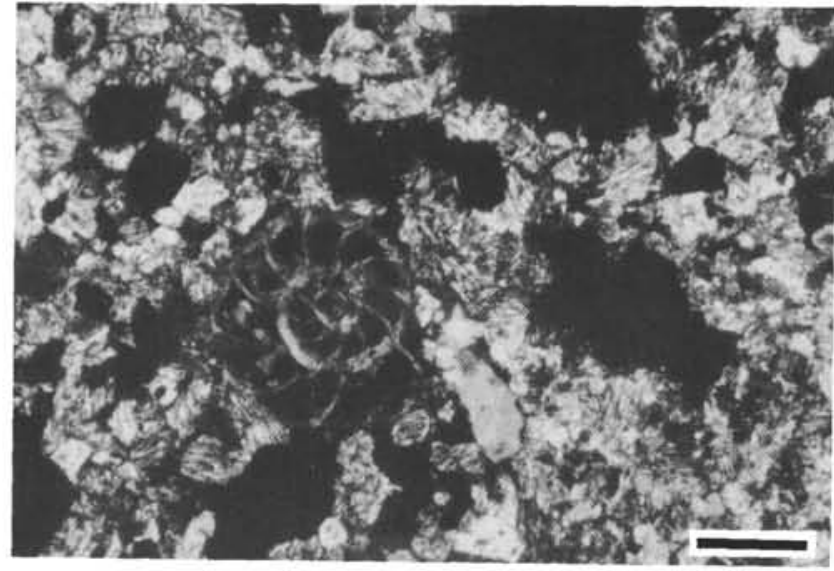

Figure 14. Clay fragments, pyrite, and biogenic constituents cemented by gypsum (227-40-2). Scale bar represents $0.1 \mathrm{~mm}$.

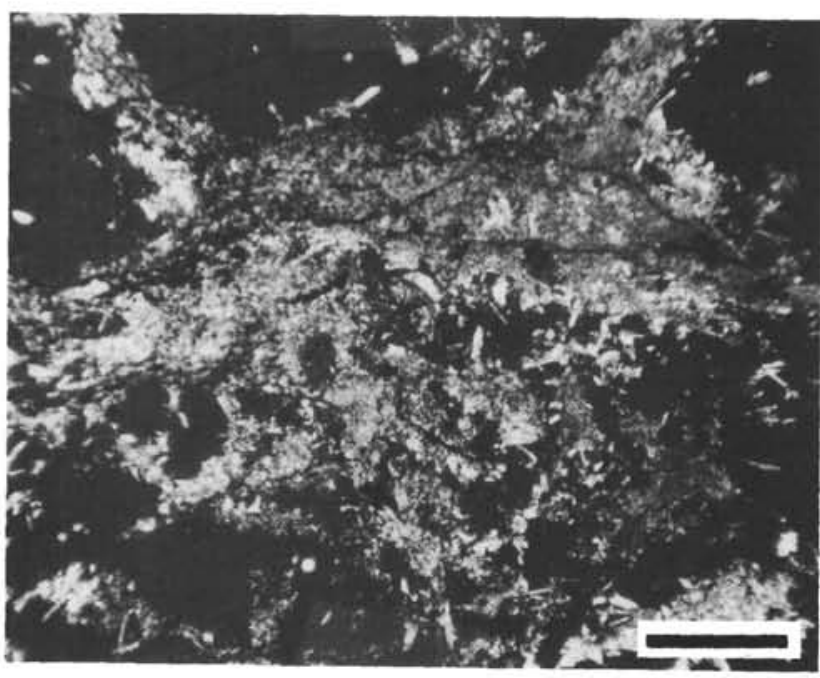

Figure 15. Clusters and needles of polyhalite in halite (225-29-3, 40-45 cm). Partially crossed nicols. Scale bar represents $1 \mathrm{~mm}$.

terrigenous sediments of Site 228 and in the lithified tuffite at Site 229. Slight to moderate bioturbation in the form of mottling and tube-like burrows was described in several cores (e.g., 227-6-2).

\section{DISCUSSION}

In general, the sediments recovered on Leg 23B can be divided into four lithologic units (Figures 2 and 3):

Unit I-gray micarb-rich detrital silty clay nanno ooze and chalk;

Unit II-gray micarb-rich nanno detrital silty claystone;

Unit III-dark gray dolomitic silty claystone; Unit IV

Unit IV-evaporites.

The oldest sediments recovered during Leg 23B are an evaporite sequence of Late Miocene or older age. A
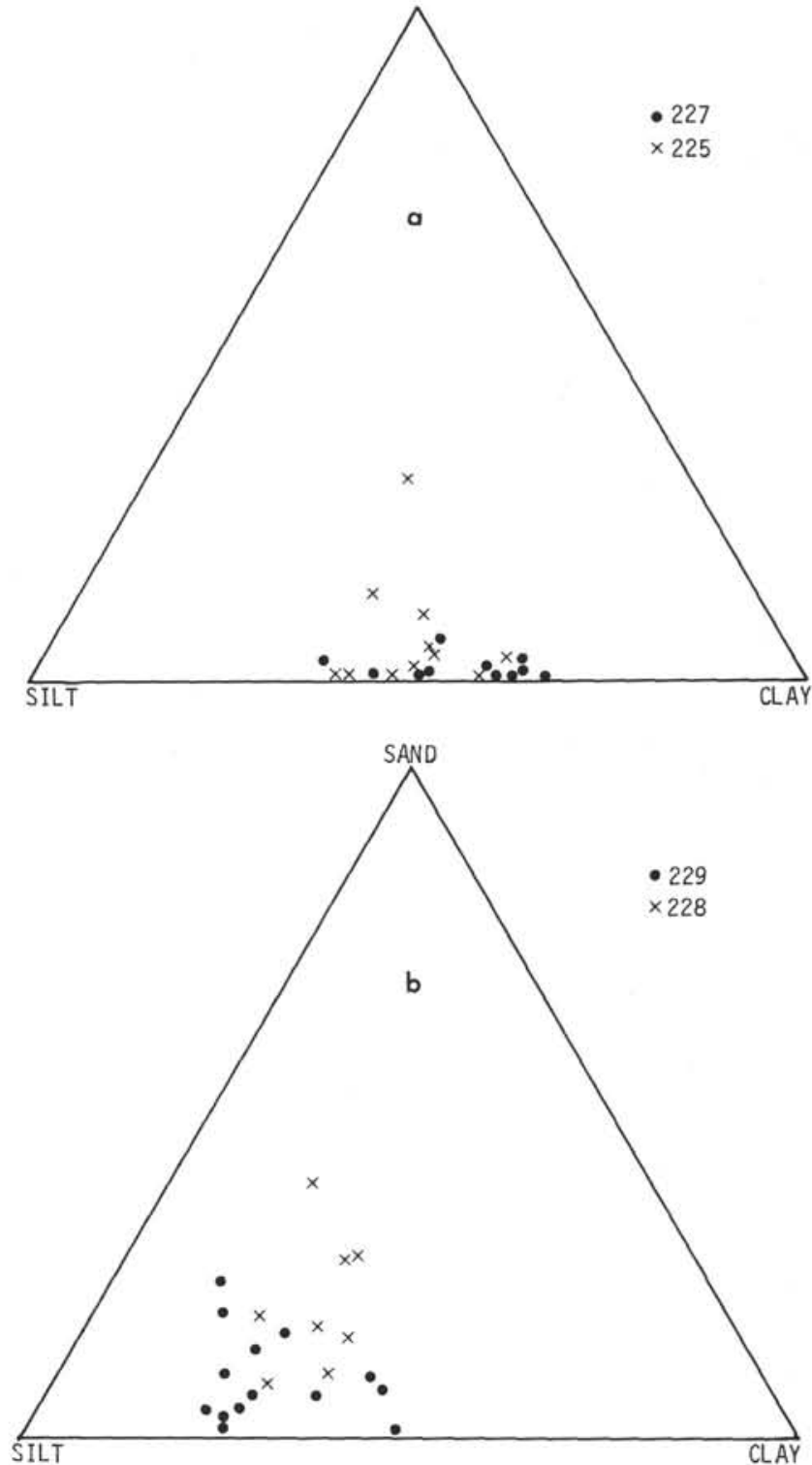

Figure 16. General texture characteristics of Red Sea sediments.

maximum of 133 meters of evaporite was drilled at Site 227. Seismic reflection information and numerous exploratory wells have shown that the Miocene evaporitic sequence with intercalated clastic material can have a thickness of more than $3 \mathrm{~km}$ (Lowell and Genik 1972; Ahmed, 1972). The Miocene marine invasion is considered to have come from the Mediterranean rather than from the Indian Ocean (Coleman, this volume). A seismic reflector in the Mediterranean (M reflector) correlates with the $\mathrm{S}$ reflector in the Red Sea, as both mark the top of a Late Miocene evaporite sequence. thus, a similar origin for the evaporites deposited in these two basins may be assumed. The Mediterranean evaporites recovered on DSDP Leg 13 have been discussed in great detail by Hsü et al. (1973), Nesteroff (1972), and Friedman (1972). Those authors generally favor the idea of a sabkha or shallow water deposition for the Mediterranean evaporites. A "desiccated 
deep-basin model" is postulated by Hsü et al. (1973) who assume the deposition of evaporites in sabkhas or playas where the water level was thousands of meters below the present Atlantic sea level. The sabkha was formed during the Late Miocene desiccation of the Mediterranean when it was completely isolated from the Atlantic Ocean.

The study of the Red Sea evaporites provides convincing evidence for a sabkha or at least a very shallow water deposition: stromatolites, oncolites, the occurrence of early diagenetic nodular anhydrite (see Stoffers and Kühn, this volume). Besides this mineralogical evidence, the isotope and pore water data (Manheim, this volume) also support the sabkha hypothesis.

The question as to whether the evaporites were deposited in a shallow water Red Sea basin or in a deep basin can be answered in favor of the deep basin model. Numerous deep exploratory wells which had been drilled in the Red Sea coastal areas penetrated great thicknesses of Miocene clastics $(2-3 \mathrm{~km})$ and evaporites $(3-4 \mathrm{~km})$ (Ahmed, 1972). The basement rocks were generally not reached. In the fractured anhydrite section of Site 228 coarse-grained detrital material is mixed with anhydrite (Figure 17). The information obtained from exploratory wells and from Leg 23B clearly demonstrates that the Red Sea depression received marginal clastic sediments alternating with the evaporites during Miocene time (Coleman, this volume). The thickness of the clastic material suggests a large relief difference between the Red Sea depression and the surrounding land.

Nannofossils and benthonic foraminifera found in the black shales between the evaporites (Site 227, Cores 31 and 36) show that fluctuations from evaporitic to marine conditions occur. The presence of these fossils also suggests an occasional open sea of considerable depth with a normal marine planktonic fauna and flora.

Due to the lack of detailed information from the deep strata it is difficult to decide whether the Red Sea evaporites were deposited in a desiccated deep basin (Hsü et al., 1973) or only reflect the final stage of a nearly filled deep-water deep-basin model (Schmaltz, 1969). Leg 23B has shown that reflector S in the Red Sea is the top of a Miocene evaporite deposit comparable to reflector $\mathrm{M}$ in the Mediterranean. Considering the idea of a repeated refilling of the Red Sea during Miocene time (which is assumed by Hsü et al. (1973) for the Mediterranean, it seems that the Schmaltz model modified by periods of desiccation caused by occasional isolation of the Mediterranean from the Atlantic might be a reasonable hypothesis to explain the Miocene evaporites in the Mediterranean and in the Red Sea.

The rigid black shales within the evaporites differ in composition and origin. The black shales at Site 225, Cores 25,26 and Site 227 Core 31 are mainly composed of dolomite, layer silicates, palygorskite, and smaller amounts of pyrite, zeolites, cristobalite, and detrital quartz and feldspar. The clay fraction is dominated by an illite-montmorillonite mixed-layer mineral. These intercalated dolomitic shales were deposited when the anhydrite or halite precipitation had stopped due to dilution of the brine. The lowermost shale intercalations at Site 225, Core 29 and Site 227 , Cores $36,40,44$, however, contain only traces of

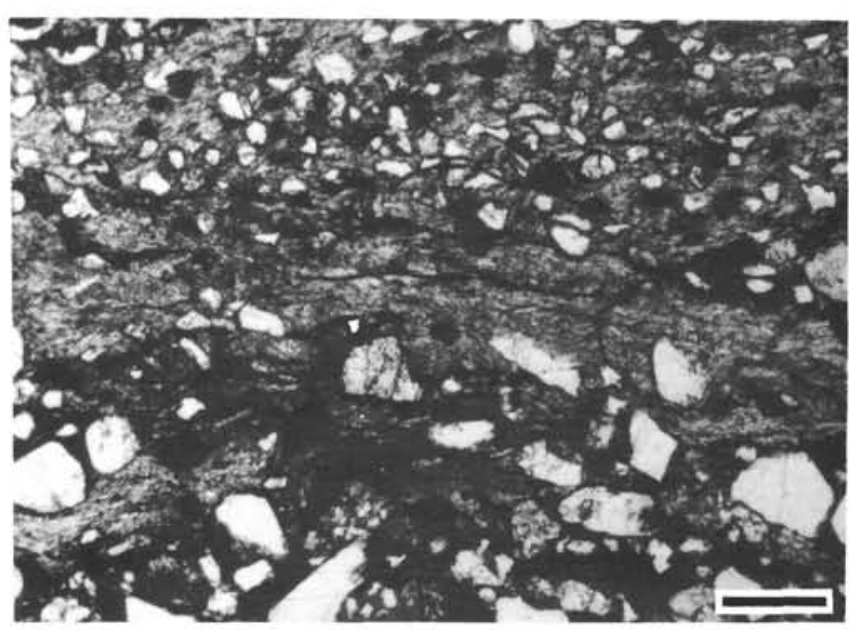

Figure 17. Clastic material in fine-grained anhydrite $(228-35-2,14-17 \mathrm{~cm})$. Scale bar represents $0.1 \mathrm{~mm}$.

dolomite. They are predominantly composed of disordered cristobalite (Site 225, Core 29, Section 1; Site 227, Core 36) and layer silicates (Site 225, Core 39, Section 2; Site 227 , Cores 40,44$)$. A very well crystallized montmorillonite (showing higher ordering) dominates $(>80 \%)$ the clay fraction. The mineralogy suggests that these shales originated from devitrification of pyroclastic material which had been deposited between the anhydrite and halite layers, respectively.

The siltstones which are interbedded with the anhydrite at Site 228 differ very much from the intercalated shales recovered at Sites 225 and 227, in showing much more detrital influence. Dolomite occurs only in small amounts. The greenish-white material in this section consists of palygorskite which locally ranges up to more than $80 \%$. Besides the scattered occurrence of palygorskite, the clay fraction is dominated by illite and chlorite-montmorillonite mixed-layer minerals. The lowermost two cores of Site 228 $(38,39)$ are characterized by abundant chlorite. The heavy metal concentration in the brecciated shale anhydrite sequence is extremely high. Euhedral sphalerite crystals were found in the shales causing zinc values of up to $5 \% \mathrm{Zn}$. The fracturing of the sediments has caused fluid movements and mineralization, and it is assumed that the black shales are the source of the metals.

\section{Unit III}

Unit III is a semilithified dark gray dolomitic silty claystone characterized by a high dolomite content and the occurrence of abundant analcite. The dolomite content varies from $\sim 10$ to $>80 \%$. The highest values were found at Site 227, Core 29, Section 5. Geochemical signatures differ between the dolomites. The dolomite in the upper part of this unit contains excess $\mathrm{Ca}\left[\left(\mathrm{Ca}_{56-59} \mathrm{Mg}_{44-41}\right) \mathrm{CO}_{3}\right]$. The dolomites just above and within the evaporites, generally of finer crystal size, have a stoichiometric composition of $\left[\begin{array}{llll}\left(\mathrm{Ca}_{50}\right. & \left.\mathrm{Mg}_{50}\right) & \mathrm{CO}_{3}\end{array}\right]$ and show better ordering (Goldsmith and Graf, 1958). Both types of dolomite are interpreted as early diagenetic with the $\mathrm{Ca} / \mathrm{Mg}$ ratio being indicative of paleosalinity conditions, analogous to the dolomites of the Zechstein (Füchtbauer, 1964; 
Füchtbauer and Goldschmidt, 1965) and the Triassic Keuper Formation (Marschner, 1968).

Microcrystalline analcite, 0.002-0.006 $\mathrm{mm}$ in diameter, is found quite often in this unit and is very abundant at Site 227 , Cores 26 to 29 (especially in Core 26). The rare occurrence of volcanic glass and the dominance of montmorillonite in the clay fraction favor the idea of a possible volcanic origin due to devitrification of volcanic material.

The high organic carbon content and up to $10 \%$ pyrite clearly indicate the deposition of this unit in a relatively restricted basin.

\section{Unit II}

Unit II is a semilithified gray micarb-rich nanno detrital silty claystone. This unit is characterized by abundant detrital material (up to $80 \%$ at Site 228). Plagioclase is the dominant detrital constituent followed by mica and quartz. Only traces of kaolinite and chlorite could be detected in the bulk sample. Nannofossil content varies between $20 \%$ and $40 \%$. The micarb particles range up to $30 \%$. Clinoptilolite is abundant in this unit. The highest value $(\sim 20 \%)$ for clinoptilolite is found at Site 227, Core 25 .

Montmorillonite, illite, and kaolinite predominate the clay fraction in this unit. Locally palygorskite is found. Dark layer intervals intercalated within the gray sediments are very abundant in this unit. The high organic carbon and pyrite content of these dark intervals suggests stagnant conditions in the Red Sea during their deposition. the values for vanadium and molybdenum in these black sediment layers are comparable to the "Mansfelder Kupferschiefer" (Manheim, this volume).

At the end of the Miocene the Red Sea opened to the Indian Ocean, open marine conditions were established, and normal marine sediments were deposited. The abundant detrital material found within these marine sediments reflects the surrounding hinterland.

\section{Unit I}

Unit $I$ is a soft to semilithified gray micarb-rich detrital silty clay nanno ooze and chalk. This unit is relatively thick, i.e., $>100$ meters at Sites 225 and 227 increasing southward to more than 200 meters which indicates a higher sedimentation rate in the Southern Red Sea. The abundance of nannofossils and micarb particles is characteristic of this unit, and locally foraminifera and pteropods range up to more than $50 \%$.

Detrital components in the bulk samples are feldspars, quartz, and mica with smaller amounts of palygorskite and traces of kaolinite, chlorite, and amphibole. The clay fraction is dominated by montmorillonite, palygorskite and some illite, kaolinite, and chlorite. At Site 228 illite and kaolinite are very abundant. At this site the high amount of detrital material can be explained as follows: During the more pluvial Plio-Pleistocene time, considerable amounts of clastic material from the interior of the Sudan were deposited on the shelf. The shallow banks found off the Sudan coast suggest a former "Sudan Delta." As the delta advanced, material was transported down into the axial valley. The heavy mineral composition in the sand fraction of Site 228 supports this explanation since the minerals are typical of the metamorphic and igneous Sudan source area.

High Mg-calcite (with $10-14 \mathrm{~mol}-\% \mathrm{Mg}$ ) is very abundant in the upper cores of this unit. The amount of high Mg-calcite and the mole-\% $\mathrm{Mg}$ decrease with increasing depth (Figure 18). This might indicate either that the conditions for the precipitation of this mineral became more and more favorable since the end of Early Pliocene time or that after deposition the high Mg-calcite is slowly transformed into calcite by diagenesis.

Lithified aragonite and Mg-calcite layers, respectively, occur quite frequently (Figure 19) although disturbed by the drilling operation in the upper cores of this unit. Milliman et al. (1969) attributed the formation of these layers to recurrent evaporation cycles caused by eustatic lowering of the sea level.

The hard welded tuffites found in the semilithified Pleistocene sediments of Site 229 are related to volcanic eruption. Their grading suggests that volcanic material was thrown into the water and deposited according to grain size. The particles were cemented by calcite. Devitrifying volcanic glass liberates alkalies and alkali-earths on weathering (Hay and Iijima, 1968), which formed clay minerals (poorly crystallized montmorillonite) and zeolites (analcime) whereas calcium formed calcium carbonate cements.

The sediments of unit I are predominantly normal marine sediments with smaller detrital admixtures. As in unit II, intercalated dark sediment layers were found. These and the lithified aragonite layers suggest that often during the Late Pliocene and Pleistocene, stagnant or more saline conditions had existed in the Red Sea.

The sites drilled during Leg 23B can be tentatively correlated with the land stratigraphy and with some of the exploratory wells drilled along the Red Sea coast. Correlations are not as rigorous as desired for three main reasons. First, the descriptions and details presented by the oil companies is considerably less than that given by the DSDP work and emphasis is on the deeper pre-Pliocene horizons. Secondly, formation names sometimes vary from one place to another. Thirdly, the boundaries of the DSDP units varies occasionally from site to site. For example, the base of unit I occurs in the Early Pliocene at Sites 225 and 227 , but in the Late Pliocene at Site 228. Thus, the age indication lines for the DSDP units are indicated as tentative. Said (1969) has reported on the general stratigraphy along some of the coastal plain areas of the Red Sea and his data and the data of others are summarized in Table 2. The location of the wells is shown on Figure 1. Most studies report the upper part of the evaporite sequence as only being post-Middle Miocene in age; thus, correlation of the top part of our unit IV (usually identified as Late Miocene or very Early Pliocene) is tentative. Correlation of units I, II, and III with the Continental Series seems reasonable since the nearshore wells probably have drilled nearshore or terrestrial facies of our marine sequences. 


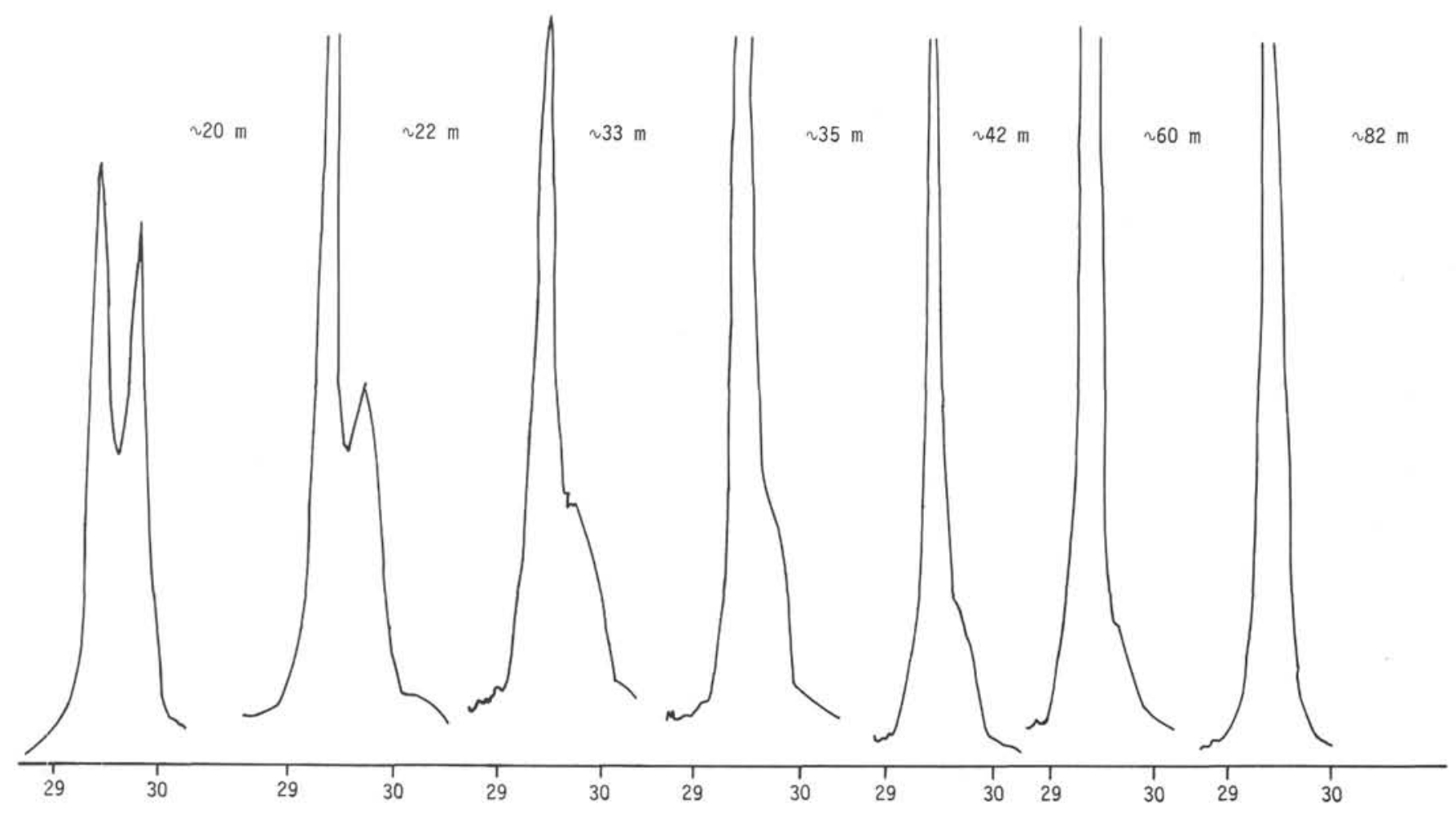

DECREASE OF Mg-CALCITE WITH CORE DEPTH

Figure 18. X-ray diffraction patterns showing decrease in Mg calcite with depth in Hole 229A.

\section{SUMMARY}

Four distinct lithological units were identified:

Unit I-gray micarb-rich detrital silty clay nanno ooze and chalk;

Unit II-gray micarb-rich nanno detrital silty claystone;

Unit III-dark gray dolomitic silty claystone;

Unit IV-evaporites.

Unit IV is an evaporite sequence of Late Miocene or older. The top of this unit is marked by an acoustic reflector (reflector S) which is correlative with a similar reflector in the Mediterranean that also represents the top of a Miocene evaporite sequence. A sabkha origin for these evaporites is suggested by their chemistry, mineralogy, isotope, and lithology. A deep-basin evaporite model is favored with occasional changes to a more normal environment indicated by nannofossils and benthonic foraminifera found in black shale interbedded between the evaporites.

Unit III, overlying the evaporites, was probably deposited in a relatively restricted basin as indicated by its high organic carbon content and up to $10 \%$ pyrite.

Units II and I were deposited within more normal marine conditions reflecting the opening of the Red Sea to the Indian Ocean. Occasional dark shale layers within unit II are enriched in vanadium and molybdenum and are comparable to the Kupferschiefer deposits (Manheim, this volume). The high organic carbon and pyrite content of these dark layers suggests deposition under stagnant conditions.

The deep-sea sediments drilled during Leg 23B can be tentatively correlated with land stratigraphy.

\section{ACKNOWLEDGMENTS}

Peter Stoffers gratefully acknowledges the financial support provided by NATO for his stay at the Woods Hole Oceanographic Institution. The assistance given by John C. Hathaway in using the X-ray computer program was gratefully appreciated.

David A. Ross was supported by a grant from the Saudi Arabian Government via the U.S. Geological Survey and would like to thank the Minister of Petroleum and Mineral Resources, Sheikh Ahmed Zake Yamani, Saudi Arabia.

The manuscript was reviewed by David A. Johnson and John C. Hathaway.

\section{REFERENCES}

Ahmed, S. S., 1972. Geology and petroleum prospects in eastern Red Sea: Am. Assoc. Petrol. Geol. Bull., v. 56, p. 707-719.

Arrhenius, G., 1963. Pelagic Sediments. In Hill, M. N. (Ed)., The sea, ideas and observations on progress in the study of the seas, v. 3. The earth beneath the sea: New York (Interscience), p. 655-727.

Backer, H. and Schoell, M., 1972. New deeps with brines and metalliferous sediments in the Red Sea: Nat. Phip. Sci., v. 240 , p. $153-158$. 
Core

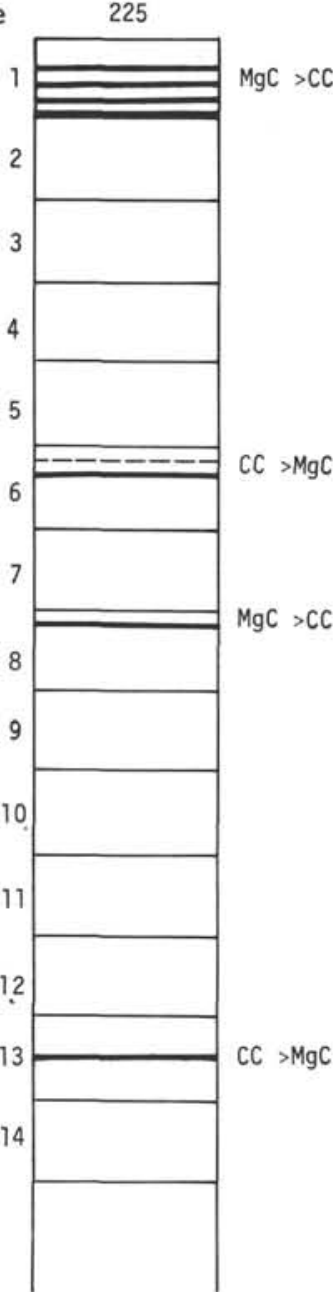

227

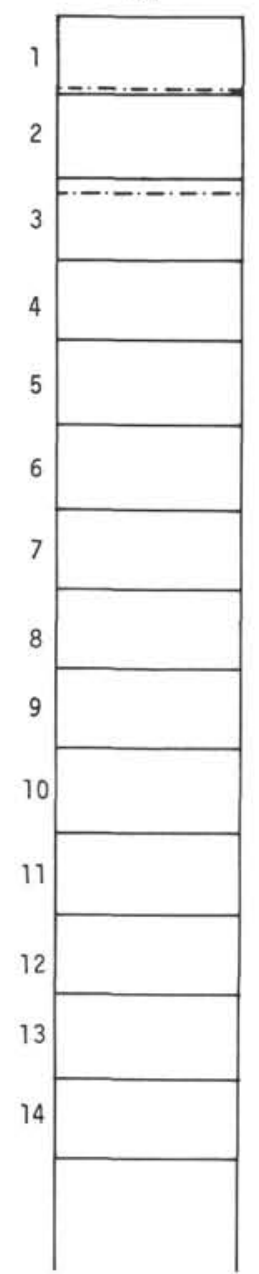

228

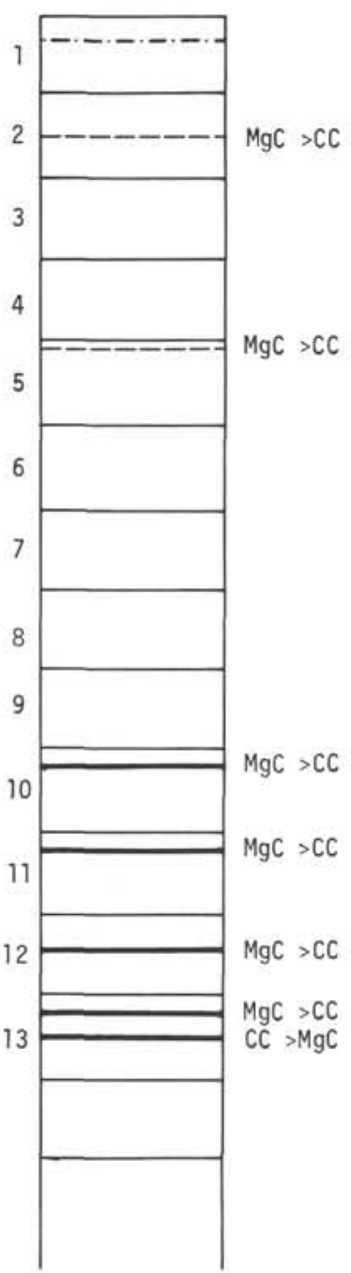

$229 \mathrm{~A}$

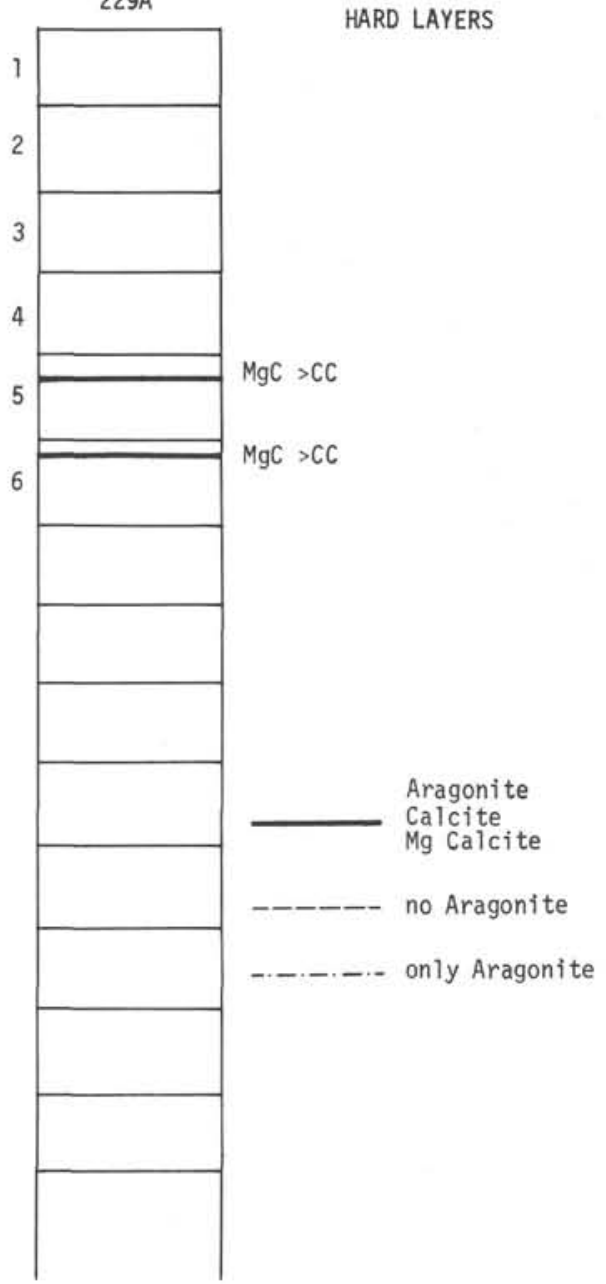

Figure 19. Distribution of lithified aragonite and $M g$-calcite layers within unit I.

Beall, A. O. and Fischer, A. G., 1969. Sedimentology of Leg I. In Ewing, M., et al., Initial Reports of the Deep Sea Drilling Project, Volume I: Washington (U. S. Government Printing Office), p. 521-585.

Biscaye, P. E., 1965. Mineralogy and sedimentation of Recent deep-sea clay in the Atlantic Ocean and adjacent seas and oceans: Geol. Soc. Am. Bull., v. 76, p. 803-832.

Bischoff, J. L., 1969. Red Sea geothermal brine deposits: their mineralogy, chemistry, and genesis. In Degens, E, T. and Ross, D. A., Hot brines and recent heavy metal deposits in the Red Sea: New York (Springer-Verlag), p. 368-401.

1972. A ferroan nontronite from the Red Sea geothermal system: Clays and Clay Minerals, v. 20, p. 217-223.

Bonatti, E., 1963. Zeolites in Pacific pelagic sediments: N. Y. Acad. Sci. Trans., v. 25, p. 938-948.

Bonatti, E. and Joensuu, O., 1968. Palygorskite from Atlantic deep sea sediments: Am. Mineralogist, v. 53,p. 975.

Carella, R. and Scarpa, N., 1962. Geological results of exploration in Sudan by AGIP Mineraria: Arab Petrol. Cong. 4th, Beirut.

Chase, R. L., 1969. Basalt from the axial trough of the Red Sea. In Degens, E. T. and Ross, D. A., Hot brines and recent heavy metal deposits in the Red Sea, New York (Springer-Verlag), p. 122-128.

Degens, E. T. and Ross, D. A., 1969. Hot brines and recent heavy metal deposits in the Red Sea: New York (Springer-Verlag).

Deuser, W. G. and Degens, E. T., 1969. O18/016 and $\mathrm{C}^{13} / \mathrm{C}^{12}$ ratios of fossils from the hot brine deep area of the Central Red Sea. In Degens, E. T. and Ross, D. A., Hot brines and recent heavy metal deposits in the Red Sea: New York (Springer-Verlag), p. 336-347.

Folk, R. L. and Pittman, J. S., 1971. Length-slow chalcedony. A new testament for vanished evaporites: J. Sediment. Petrol., v. 41, no. 4.

Frazier, S. B., 1970. Adjacent structures of Ethiopia: that portion of the Red Sea coast including Dahlak Kebir Island and the Gulf of Zula: Phil. Trans. Roy. Soc. London, Series A, v. 267, p. 131-142.

Friedman, G. M., 1971. Petrographic Data and Comments on the depositional environment of the Miocene sulfates and dolomites at Sites 124, 132, and 134, western Mediterranean Sea. In Ryan, W.B.F., Hsü, K. J., et al., Initial Reports of the Deep Sea Drilling Project, Volume XIII: Washington (U. S. Government Printing Office), p. 695-707.

Füchtbauer, H., 1964. Fazies, Porosität. und Gã̃sinhakt der Karbonatgesteine des norddeutschen Zechsteins: Z. Deutschen Geol. Gesell., v. 114, p. 484-531. 
TABLE 2

General Stratigraphy of the Post-Middle Miocene Red Sea Sediments

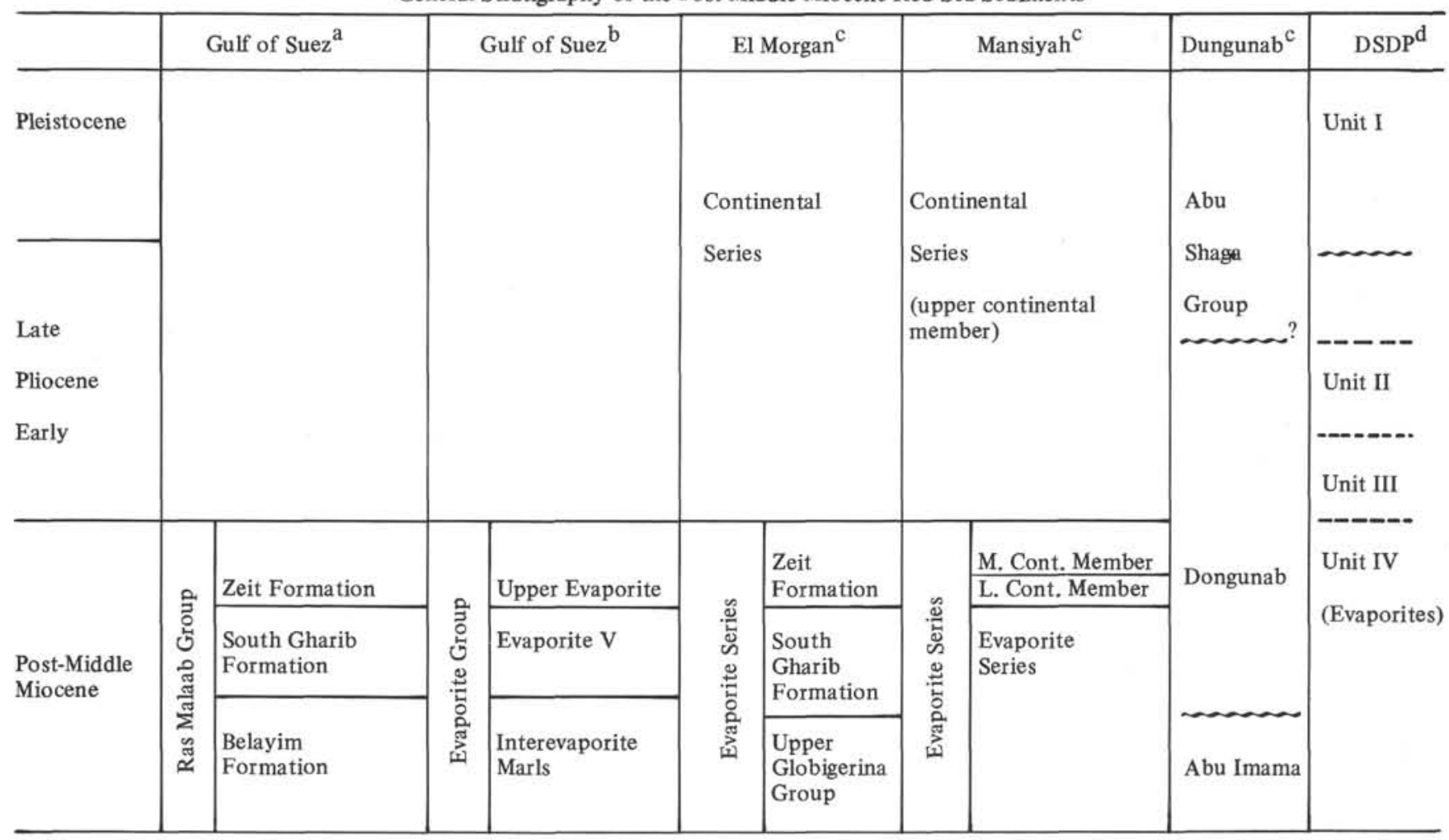

NOTE:

unconformity; tentative boundary

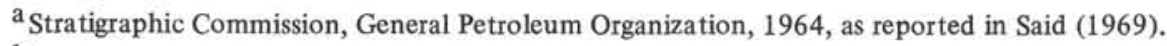

baid and El-Heiny (1967).

${ }^{\mathrm{c}}$ See Figure 1 for location.

$\mathrm{d}_{\text {Sites 225, 227, } 228 .}$

Füchtbauer, H. and Goldschmidt, H., 1965. Beziehungen zwischen Calciumgehalt und Bildungsbedingungen der Dolomite: Geol. Rund., v. 55, p. 29-40.

Gass, I. G., 1970. The evolution of volcanism in the junction area of the Red Sea, Gulf of Aden, and Ethiopian Rifts: Phil. Trans. Roy. Soc. London, Series A, v. 267, p. $369-381$.

Gevirtz, J. L. and Friedman, G. M., 1966. Deep-sea carbonate sediments of the Red Sea and their implications on marine lithification: J. Sediment. Petrol., v. 36, p. 143-151.

Gillmann, M., 1968. Preliminary results of a geological and geophysical reconnaissance of the Gizan coastal plain in Saudi Arabia: AIME Symp. Dhahran, Saudi Arabia, p. 198-208.

Goldsmith, J. R. and Graf, D. L., 1958. Structural and compositional variations in some natural dolomites: J. Geol., v. 66, p. 678-693.

Grimm, W. D., 1962. Idiomorphe Quarze als Leitmineralien für salinare Fazies: Erdöl Kohle, v. 15, p. 880-887.

Hathaway, J. C. and Sachs, P. L., 1965. Sepiolite and clinoptilolite from the Mid-Atlantic Ridge: Am. Mineralogist, v. 50, p. $852-867$.

Hathaway, J. C., McFarlin, P. F., and Ross, D. A., 1970. Mineralogy and origin of sediments from drill-holes on the Continental margin off Florida: U.S. Geol. Surv. Professional Paper 581-E.

Hay, R. L. and Iijima, A., 1968. Nature and origin of palagonite tuffs of the Honolulu Group on Oahu, Hawaii: Studies in Volcanology: Coats, Hay, and Anderson (Eds.), Geol. Soc. Am. Memoir, v. 116, p. 331-376.

Heezen, B. C., Nesteroff, W. D., Oberlin, A., and Sabatier, G., 1965. Découverte d'attapulgite dans les sédiments profonds du golfe d'Aden et de la Mer Rouge: Compte. Rand. Acad. Sci. Paris, v. 260, p. 5819-5821.

Herman, Y., 1965. Evidence of climatic changes in Red Sea cores. In Morrison, R. B. and Wright, H. E. (Eds.), Means of correlation of quaternary successions: v. 8, University of Utah Press, p. 325-348.

Holser, W. T., 1966. Diagenetic polyhalite in recent salt from Baja California: Am. Mineralogist, v. 51, p. 99-109.

Hsü, K. J., Cita, M. B., and Ryan, W. B. F., 1973. The origin of the Mediterranean evaporites. In Ryan, W. B. F., Hsü, K. J., et al., Initial Reports of the Deep Sea Drilling Project, Volume XIII, Washington (U.S. Government Printing Office), p. 1203.

Keller, W. D., 1952. Analcime in the Popo Agie member of Chugwater formation: J. Sediment. Petrol., v. 22, p. 70-82. 
Lancelot, Y., Hathaway, J. C., and Hollister, C. D., 1972. Lithology of sediments from the western North Atlantic Leg 11 Deep Sea Drilling Project. In Hollister, C. D., Ewing, J. I., et al., Initial Reports of the Deep Sea Drilling Project, Volume XI: Washington (U. S. Government Printing Office), p. 901-950.

Lowell, J. D. and Genik, G. J., 1972. Sea-floor spreading and structural evolution of southern Red Sea: Am. Assoc. Petrol. Geol. Bull., v. 56, p. 247-259.

Marschner, H., 1968. Ca-Mg-Distribution in the Lower Keuper of NW-Germany. In Müller, G. and Friedman, G. M. (Eds), Recent developments in carbonate mineralogy of central europe: Berlin-Heidelberg-New York (Springer-Verlag).

Mason, J. F. and Moore, Q. M., 1970. Petroleum developments in Middle East countries in 1969: Am. Assoc. Petrol. Geol. Bull., v 54, p. 1524.

Miller, A. R., Densmore, C. D., Degens, E. T., Hathaway, J. C., Manheim, F. T., McFarlin, P. F., Pocklington, R., and Jokela, A., 1966. Hot brines and recent iron deposits of the Red Sea: Geochim. Cosmochim. Acta, v. 30 , p. 341.

Milliman, J. D., Ross, D. A., and Ku, T. L., 1969. Precipitation and lithification of deep-sea carbonates in Red Sea: J. Sediment. Petrol., v. 39, p. 724-736.

Millot, G., 1970. Geology of clays. Weathering, sedimentology, geochemistry: New York (Springer-Verlag), p. 172-174.

Müller, G., 1961a. Die rezenten Sedimente im Golf von Neapel. 2. Mineral-Neu-und Umbildungen in den rezenten Sedimenten des Golfes von Neapel. Ein Betrag zur Umwandlung vulkanischer Gläser durch Halmyrolyse: Contr. Miner. Petrog., v. 8, p. 1-20.

$1961 \mathrm{~b}$. Palygorskit und Sepiolith in tertiären und quartären Sedimenten von Hadramaut (S-Arabien): Neues Jahrb. Mineral., Abhandl., v. 97, p. 275-288.

Nayudu, Y. R., 1964. Palagonite tuffs (hyaloclastites) and the products of post-eruptive processes: Vulcanologique Bull., v. 27, p. 1.

Nesteroff, W. D., 1972. Mineralogy, Petrography, Distribution, and Origin of the Messinian Mediterranean evaporites. In Ryan, W. B. F., Hsü, K. J., et al. Initial Reports of the Deep Sea Drilling Project, Volume XIII: Washington (U.S. Government Printing Office), p. 673-694.

Norin, E., 1953. Occurrence of authigenous illitic mica in the sediments of the central Tyrrhenian Sea: Geol. Inst. Univ. Upsala Bull., v. 34, p. 279.

Peterson, M. N. A., Edgar, N. T., von der Borch, C. C., and Rex, R. W., 1970. Cruise Leg Summary and discussion. In Peterson, M.N.A. et al., 1970. Initial Reports of the Deep Sea Drilling Project, Volume II: Washington (U. S. Government Printing Office), p. 413.

Ross, D. A. and Schlee, J., in press. Shallow structure and geologic development of the Southern Red Sea: Geol. Soc. Am. Bull.

Said, R., 1969. General stratigraphy of the adjacent land areas of the Red Sea: In Degens, E. T. and Ross, D. A. (Eds.), Hot brines and recent heavy metal deposits in the Red Sea: New York (Springer-Verlag), p. 71-81.

Said, R. and El-Heiny, I., 1967. Planktonic foraminifera from the Miocene rocks of the Gulf of Suez region: Egypt Contr. Cushman Found. Foram. Res., v. 18, p. 14.

Schmalz, R. F., 1969. Deep-water evaporite deposition: a genetic model: Bull. Am. Assoc. Petrol. Geol. Bull., v. 53, p. 758 .

Swartz, D. H. and Arden, D. D., Jr., 1960. Geologic history of the Red Sea area: Am. Assoc. Petrol. Geol. Bull., v. 44 , p. $1621-1637$.

von Rad, U. and Rösch, H., 1972. Mineralogy and origin of clay minerals, silica and authigenic silicates in Leg 14 sediments. In Hayes, D. E., Pimm, A. C., et al., Initial Reports of the Deep Sea Drilling Project, Volume XIV: Washington (U.S. Government Printing Office), p. 727-752. 